\title{
THE INFLUENCE OF SIMAZINE ON METABOLISM OF PROTEIN AND RIBONUCLEIC ACID IN OAT PLANTS (Avena sativa L.)
}

\author{
By \\ RAGHVENDRA PAL SINGH
}

\begin{abstract}
A DISSERTATION PRESENTED TO THE GRADUATE COUNCIL OF THE UNIVERSTTY OF FLORDA

IN PARTIAL FULFILLMENT OF THE REQUIREMENTS FOR THB DEGREE OF DOCTOR OF PHILOSOPHY
\end{abstract}

UNIVERSITY OF FLORIDA

December, 1964 


\section{ACKONOWLEDGMENTS}

The author wishes to express his deep gratitude to Dr. S. H. West, Plant Physiologist, Co-chairman of the Supervisory Committee, under whose direction the work was carried out, for his valuable help and constructive criticism during the course of the research and preparation of this manuscript.

Deep appreciation is also extended to Dr. E. G. Rodgers, Professor of Agronomy, Chairman of the Supervisory Committee for his valuable advice and constructive criticism during the course of the preparation of this manuscript.

The author is greatly indebted to Dr. F. H. Hull, Head of the Department of Agronomy for providing financial help. The author gladly acknowledges the financial grant awarded by the American Institute of Biological Sciences and Asia Foundation for the preparation of this manuscript. With deep gratitude he acknowledges the advice and criticism of Dr. M. Wilcox, Assistant Professor of Agronomy; Dr. G. R. Noggle, former Head of the Department of Botany; Dr. V. F. Nettles, Professor of Vegetable Crops and Dr. T. E. Humphreys, Associate Professor of Botany.

The writer would also like to convey his sincere thanks to Joel E. Smith and Mrs. V. M. Barker for their technical help in the experiments reported in this dissertation. 


\section{TABLE OF CONTENTS}

\section{Page}

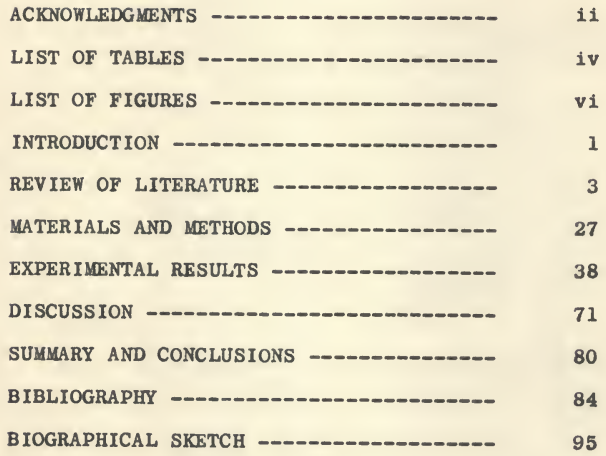


LIST OF TABLES

Table

Page

1. A COMPARISON OF THE CHANGES OF FRESH AND DRY WEIGHTS OF OAT PLANTS TREATED WITH

SIMAZINE -

2. CHANGES IN TOTAL PROTEIN OF OAT SHOOTS

CAUSED BY SIMAZINE TREATMENTS -

3. ANALYSIS OF VARIANCE OF FOUR SIMAZINE

EFFECTS ON OATS

4. CHANGES IN TOTAL RNA CONTENT OF OAT SHOOTS

CAUSED BY SIMAZINE TREATMENTS -

5. CHANGES IN CHLOROPHYLL CONTENT OF OAT SHOOTS CAUSED BY SIMAZINE TREATMENTS -

6. ANALYSIS OF VARIANCE OF CHLOROPHYLL CONTENT OF OATS

7. A COMPARISON OF CHANGES OF ALCOHOL-SOLUBLE AMINO ACIDS OF OAT PLANTS FROM SAND TREATED WITH SIMAZINE

8. ANALYSIS OF VARIANCE OF CONTENT OF FREE AMINO ACIDS OF OATS -

9. PART ICULATE PROTEINS OF OAT SHOOTS AS INFLUENCED BY SIMAZINE TREATMENTS -

10. ANALYSIS OF VARIANCE OF CONTENT OF PARTICULATE PROTEINS OF OATS -

11. RATE OF INCORPORATION OF $\mathrm{C}^{14}$-LEUCINE IN TOTAL AND CHLOROPLAST PROTEINS OF CHECK AND SIMAZINE TREATED OAT SHOOTS

12. RATE OF INCORPORATION OF $\mathrm{C}^{14}$-LEUCINE IN TOTAL AND CHLOROPLAST PROTEINS OF 10-DAY OLD SHOOT TISSUE INCUBATED WITH AND WITHOUT SIMAZINE -- 
13. RATE OF INCORPORATION OF $C^{14}$-LEUCINE IN TOTAL AND CHLOROPLAST PROTEINS OF CHECK AND SIMAZINE TREATED 10-DAY OLD OAT SHOOTS INCUBATED WITH AND WITHOUT GLUCOSE

14. RATE OF INCORPORATION OF $\mathrm{C}^{14}$-LEUCINE IN TOTAL PROTEIN OF CHECK AND SIMAZINE TREATED 10-DAY OLD OAT SHOOT TISSUE GROWN IN LIGHT AND DARK -

15. INFLUENCE OF SIMAZINE $Q N$ RNA CONTENT AND RATE OF INCORPORATION OF P $^{32}$ IN RIBOSOMES OF OAT SHOOTS ARISON OF CHANGES IN THE RATIOS OF

16. A COMPARISON OF CHANGES IN THE RATIOS OF
DIFFERENT RIBOSOMES IN OAT PLANTS TREATED WITH SIMAZINE 


\section{LIST OF FIGURES}

Figure

Page

1. Influence of different rates of simazine on the growth of oat plants, five days after

treatment -

2. Influence of different rates of simazine on the growth of oat plants, six days after treatment

3. Influence of different rates of simazine on the growth of oat plants, eight days after treatment

4. Influence of different rates of simazine on the growth of oat plants, 10 days after

treatment _.

5. Influence of different rates of simazine on the growth of oat plants, 13 days after treatment

6. Influence of simazine on the RNA content of different sizes of $r$ ibosomes and the rate of incorporation of $\mathrm{p} 32$ in the RNA of different sizes of ribosomes 


\section{INTRODUCTION}

Weeds are among the most serious obstacles in the production of crops. The science of weed control has undergone more advancement during the last two decades than in the past centuries of recorded history. Old methods of weed control are being replaced with chemical techniques that provide far superior control at reduced cost.

According to the British Weed Control Council (16), 71 herbicides were named in 1960. Yet, in actual practice, some three quarters of all chemical weed control is now achieved with just three chemicals, their homologues or analogues. One of these chemicals is simazine (2-chlor 0-4, 6-bis(ethylamino)-s-triazine), an effective, selective, pre-emergence herbicide for weed control in corn.

The knowledge of the influence of herbicides on physiological processes and the biochemical constituents of plants is useful in the understanding of the mode of action of herbicides and developing efficient weed control practices. In the past years, it has been established that simazine inhibits photosynthesis by influencing the Hill reaction $(34,96)$ and $\mathrm{CO}_{2}$ fixation $(8,130)$. 
As yet, no attempt has been made to understand the influence of simazine on protein and ribonucleic acid (RNA) metabolism of plants. Protein and nucleic acid metabolism are essential processes which greatly influence growth and development of plants.

This investigation was designed, therefore, to explore the influence of simazine on protein and RNA metabolism of oat plants. Secondary objectives included the determination of the influence of simazine on plant growth and the content of chlorophyll and free amino acids. Radioisotope $\mathrm{C}^{14}$-leucine and $\mathrm{p}^{32}$ were used in this investigation to gain a better understanding of the influence of simazine on the synthesis of protein and RNA. 


\section{REVIEW OF LITERATURE}

Simazine and atrazine (2-chloro-4-ethylamino6-isopropylamino-s-triazine) have proven to be outstanding chemicals for weed control in corn $(19,47,83)$. Simazine was synthesized by Gysin and Knisli in the laboratory of J. R. Geigy, Basle, Switzerland and was released for experimental purposes in 1956 (93). Simazine is a selective pre-emergence herbicide effective in the control of broad leaf weeds and annual grasses (100). The most common weeds controlled by this herbicide, are carpet weed, wild carrot, wild onion, lambsquarter, narrow-leaved plantain, purslane, rag weed, foxtailgrass, barnyardgrass, quackgrass and some other annual grasses $(18,47)$.

Greenhouse and field studies indicated that tall fescue and alfalfa forage crops are the most tolerant to atrazine, timothy is the most susceptible and red clover, Korean lespedeza, ladino clover, sweetclover, orchardgrass and bromegrass are intermediate in their response to atrazine (36).

Sugarcane, brambles, grapes, asparagus, strawberries, pineapple, citrus, milo, spinach and walnut were found to be tolerant to simazine (93). Cotton response is intermediate and cucumber, oats, barley and wheat are susceptible to simazine (19). 
Uptake and Translocation

Many of the less water-soluble herbicides of the s-triazine group are effective only when absorbed by the roots. Simazine apparently penetrates the cuticle readily but subsequently moves only in an acropetal direction by diffusion along cell walls and does not enter readily in the living symplast (25). Other s-triazines follow the same pattern of distribution when applied to the leaves (25).

These compounds are readily absorbed by roots from the culture medium $(28,93)$. Biswas (14) found that $\checkmark$ atrazine moves both acropetally and basipetally, whereas simazine moves only in acropetal direction. Simazine is translocated in the acropetal direction in association with the transpiration stream $(28,38,39,50,95)$. The foliar absorption and translocation of simazine in the symplasm of corn, soybean, cucumber and cotton were found to be negligible $(28,38,39)$.

A significant difference in the rate of atrazine-cl4 absorption by the upper and lower surfaces of peanut leaves was demonstrated by Biswas (14).

Simazine or $\mathrm{C}^{14}$-labeled products, according to Davis et al. (28), are translocated from roots to leaves in cucumber in less than 0.5 hour. The radioactivity was first confined to the vein but after eight hours, the herbicide accumulated in the leaf margins and interveinal areas. Simazine was distributed throughout oat seedlings within three hours (95) and within 6-12 hours in seedlings of several evergreen and deciduous tree species (50). 
Light, temperature, relative humidity and the concentration of herbicide influenced simazine absorption (84, 95). Increased uptake and translocation of simazine-C 14 in corn under constant light had been reported by Plaisted and Ryskiewich (84). Sheets (95) found more absorption and translocation of simazine in oat seedlings at $37^{\circ} \mathrm{C}$ and 33 per cent relative humidity than at $26^{\circ} \mathrm{C}$ and 66 per cent relative humidity.

Various loci for accumulation of degraded products of simazine-C 14 in different plants have been reported by Davis et al. (28). These products accumulated in the edges of cucumber leaves, in the lysigenous glands of stem and in the leaf edges of cotton and in the entire corn plant. Foy (37) also reported its accumulation in the lysigenous glands of cotton. He did not find an accumulation of 2-hydroxy simazine in this gland.

\section{Degradation of Herbicide}

Corn is tolerant to s-triazine herbicides due to detoxication of the herbicide. Studies with ringlabeled simazine have demonstrated that both tolerant and susceptible species degrade simazine, particularly in the roots $(21,70,96,100)$. Simazine is dechlorinated to its 2-hydroxy analogue by a non-enzymatic detoxication mechanism $(22,51)$. The degraded product, 2-hydroxysimazine (2-hydroxy-4, 6-bis(ethylamino)-s-triazine) has been isolated from maize seedlings and excised roots (54). 
Roth (90) found a factor in maize extracts which was not present in wheat extracts and was heat-labile in crude extracts, but heat-stable after purification. This factor was identical to a compound from maize identified as 2,4-dihydroxy-7-methoxy-1,4-benzoxazin-3-one (53). The compound from maize and its glucoside converted simazine to hydroxysimazine in vitro (54).

In addition, other chemical and physiological systems may be involved in simazine detoxication.

1. Castelfranco and Brown (21) observed that hydroxylamine or pyrimidine converted simazine to its 2-hydroxy analogue in vitro.

2. Roth (91) observed that simazine is degraded by phenols and peroxidase. Resistant plants had high peroxidase activity and low catalase activity in comparison to susceptible species. A phenol-peroxidase system capable of breaking the heterocyclic nucleus of triazine has been obtained from maize. Both resistant and susceptible plant species cleaved the triazine ring of ring-labeled simazine $(70,85)$ and atrazine, and released $\mathrm{C}^{14} \mathrm{~L}_{2}$. Initial release of $\mathrm{Cl}^{14} \mathrm{O}_{2}$ was higher from susceptible cucumber than from maize, but the chloroform-soluble fraction (probably unaltered simazine) was also higher in cucumber (85).

In general, the selective action of simazine seems to be associated with processes which prevent accumulation of the unaltered molecule at the site of action in the leaves (28, 96). However, Gysin and Knüsli (51) found accumulation of a considerable amount of unaltered simazine in a resistant plant.

Recently, Hamilton (52) found a single gene honozygous recessive mutant in an $s_{1}$ inbred line of corn which resulted in an 8-10 fold reduction in 2,4-dihydroxy7-methoxy-1,4-benzoxazin-3-one (simazine resistant factor) content. Tolerance studies on $3: 1$ and $1: 1$ segregating ears 
indicated that the low segregates are somewhat less tolerant to atrazine. Eastin et al. (33) found G.T.112 line of corn to be susceptible to simazine and atrazine.

\section{Injury Symptoms}

The typical symptom of simazine toxicity is chlorosis which starts at the leaf tip and progresses along the margins to the base of the leaf. Necrosis of the tissue occurs in the chlorotic area. Chlorosis spreads rapidly to the entire leaf surface followed by death of the leaf and eventually the entire plant. The death of the entire plant results, particularly if enough moisture is present to leach the chemical to root depth (93). Rodgers and Wilcox (89) found that the phytotoxicity symptoms of triazines in Lakeland fine sandy soil are evident 7 to 10 days after planting as leaf chlorosis in oats and leaf chlorosis, stem binding and breaking in cucumber. These plants died 14 days after planting.

\section{Influence on Plant Anatomy}

Ashton et al. $(5,6)$ studied the structural changes in Phaseolus vulgaris induced by atrazine. These workers observed the following histological changes:

1. Precocious development of vacuoles and a modified ontogeny of chloroplast in the developing leaves.

2. Chloroplast destruction and reduced airspace system in the matured primary leaves.

3. Cessation of cambial activity and decrease in the thickness of the cell walls of sieve and tracheary elements in the stem. 
They studied these changes in simazine treated plants under light and dark conditions, and in the control plants placed in dark and light. They concluded that the accelerated vacuolation effect probably is due to the block in photosynthesis, but the chloroplast disintegration, reduced airspace system and cessation of cambial activity are not dependent exclusively on the photosynthetic block. Ashton et al. (6) also studied the effect of atrazine on the fine structure of chloroplasts. The following results were observed:

1. Chloroplasts become spherical in form rather than discoid.

2. Then they become aggregated in the equatorial zone of the cell.

3. Eventually the individual chloroplasts disintegrate and the entire cell is filled with a substance which has a great affinity for a certain dye.

4. The ectoplast and tonoplast are modified.

In addition, Ashton et al. (6) have shown that chloroplasts from plants treated with atrazine and kept in the light undergo the following changes:

1. Starch disappears from the lamellar system.

2. The frets or part of the frets are destroyed, and further grana arrangement is disorganized.

-3. Progressive swelling of the grana compartments.

4. In the late stages of the effect, the chloroplast envelope and compartment membranes are broken.

Wakonig and Arnason (111) have reported that 2,4,6-tris(ethylamino) -1,3,5-triazine caused chromosome breaks and chromatid interchange in the root tips of Vicia and Allium. 
Physiological and Biochemical Effects

Interaction of light and triazines: Atrazine and

$\longrightarrow$ simazine are active only in the presence of light (2). Ashton (3) found characteristics leaf injury symptoms of atrazine to red kidney and oat plants only in the presence of light. Less injury was observed at lower light intensities. The action spectrum corresponded to the absorption spectrum of chlorophyll. The nature of this interaction of atrazine and light to produce phytotoxicity is not known. However, Ashton et al. (6) postulated the possibility of the formation of one or more secondary toxic substances responsible for this effect. They also suspected that one or more "free radicals" of this substance may exist.

The results of the various investigations reveal that photosynthesis is the process which is most sensitive to phytotoxic effects of triazines. Several investigators have demonstrated that simazine inhibits starch (45), sucrose-C ${ }^{14}$ formation in leaves (8), oxygen release in Elodea (91) and $\mathrm{CO}_{2}$ utilization by illuminated bean leaves (8).

Hill reaction: Simazine inhibits the photochemical activity of isolated chloroplasts, according to many investigators. All the active herbicides of the s-triazine group gave 50 per cent inhibition of the Hill reaction at concentrations between $10^{-4}$ and $10^{-9} \underline{\underline{M}}$ with the 50 per cent inhibition at a simazine concentration of $7 \times 10^{-9} \underline{M}(34,35)$. 
Sheets (96) reported that a $4.6 \times 10^{-6} \underline{M}$ simazine concentration caused the inhibition of the Hill reaction. Moreland (71) also found 50 per cent inhibition for isolated barley chloroplasts at $4.6 \times 10^{-6} \underline{M}$ simazine concentration. The simazine concentration required for 50 per cent inhibition of the Hill reaction had been established by Moreland and Hill (72).

According to Roth (91), triazines inhibit photosynthesis but increase oxygen consumption in respiration in green plants.

Good (48) and Bishop (13) concluded that inhibition results from interference with the mechanism of oxygen production. All phytotoxic triazines seem to inhibit the Hill reaction, but the degree of inhibition does not always parallel the herbicidal effectiveness (51). Hill reaction activity of chloroplasts from simazinesensitive and simazine-tolerant species is inhibited equally $(34,71,72)$ and the mechanism controlling selectivity consequently seems to be located outside the chloroplasts.

$\mathrm{CO}_{2}$ fixation: Photosynthesis is inhibited in simazineresistant species, but van Oorschot and Belksma (109) showed that $\mathrm{CO}_{2}$ utilization by maize returns to normal within a few weeks after treatment.

Ashton et al. (8) reported the effects of different concentrations and exposure periods of simazine on $\mathrm{CO}_{2}$ fixation by bean plants. After 40 hours of exposure 
to 0.25 p.p.m. simazine concentration, the $\mathrm{CO}_{2}$ fixation decreased to 30 per cent. The $\mathrm{CO}_{2}$ fixation was nearly blocked when the tissue was treated with 1 p.p.m. simazine. In the exposure period study, $\mathrm{CO}_{2}$ fixation was inhibited after an exposure perlod of three hours.

Zweig and Ashton (130) treated excised bean leaves with varying concentrations of atrazine for different time periods. The $\mathrm{CO}_{2}$ fixation was normal at al1 exposure times when tissue was treated with $0.1 \mathrm{p} . \mathrm{p} . \mathrm{m}$. atrazine. At 1 p.p.m., $\mathrm{CO}_{2}$ fixation was reduced to 10 per cent after 50 hours of exposure. A higher concentration of atrazine was more effective in the inhibition of $\mathrm{CO}_{2}$ fixation. Results of these workers showed that atrazine could not completely block $\mathrm{CO}_{2}$ fixation, even at relatively high concentrations and long exposure. In the above experiment, 1 per cent $\mathrm{CO}_{2}$ fixation was found when the tissue was exposed 100 hours to $10 \mathrm{p} . \mathrm{p} . \mathrm{m}$.

According to Zweig and Ashton (130), atrazine treatment greatly modifies the course of organic compound synthesis in bean leaves. The results of their experiment demonstrated that sucrose synthesis had been completely inhibited by atrazine, but that the concentration of aspartic acid had increased and glycine disappeared. Citric acid, serine and asparagine also were affected. These results indicated that atrazine affects mostly the products of tricarboxylic acid cycle, which suggests that respiration and dark $\mathrm{CO}_{2}$ fixation resembled the pattern of leaves 
treated with 10 p.p.m. atrazine for 72 hours. Aspartic acid was greatly increased and malic acid, serine, glutamic acid and asparagine were present only in detectible amounts, but sucrose-c ${ }^{14}$ was completely lacking. They concluded that the disappearence of the products of photosynthesis (sucrose, glyceric acid) and labeling of aspartic acid and malic acid are due to the phosphoenol carboxylase activity.

The $\mathrm{C}^{14} \mathrm{O}_{2}$ fixation in the atrazine treated leaves was compared by Zweig and Ashton (130) with the untreated leaves under dark treatment. They found that the C-1 carboxyl label of aspartic acid represented 64 per cent of the total activity in the atrazine treated leaves and 57 per cent in the dark treatment. On the basis of these findings, these investigators concluded that the same mode of $\mathrm{C}^{14} \mathrm{O}_{2}$ fixation is operative in both leaves.

Carbohydrate: The control of quackgrass by atrazine has been correlated by Schirman and Buchholtz (92) with the depletion of carbohydrate in the rhizomes. Several experiments have been carried out to illustrate the effects of feeding of sugar and organic acids on the toxic effects of simazine and atrazine. Glucose supplied to barley seedlings was effective in keeping plants alive in the presence of lethal concentration of simazine (71). Ashton and Uribe (7) studied effect of feeding sucrose-C 14 to atrazine treated excised bean leaves on the 
distribution of radioactivity in various labeled compounds. In the presence of sucrose-c ${ }^{14}$ substrate and light, atrazine treatment decreased serine, alanine and glyceric acid biosynthesis and increased aspartic acid and glutamic acid biosynthesis. Similar results were obtained in the treatment where check plants were grown in the dark. The only exception in these treatments was that the alanine and glutamic acid were not affected in the dark. When serine-C ${ }^{14}$ was used as substrate in the above condition, atrazine treatment decreased malic acid and citric acid biosynthesis and increased alanine, threonine, aspartic acid and glutamic acid biosynthesis. Results under light and dark conditions were similar.

Allen and Palmer (2) reported that the toxic effects of simazine can be overcome by feeding sucrose, glucose, aspartate and maltose to plants. More soluble carbohydrates were in the glucose and maltose fed shoots. plants fed with glutamine and asparagine were high in total nitrogen. The nitrogen content of the sucrose and maltose fed plants was increased, but nitrogen content was not increased in the plants fed with glucose.

Transpiration: A severe reduction in transpiration rate is caused by the treatment of atrazine and other inhibitors of photosynthesis. Smith and Buchholtz (101) $\checkmark$ attributed this reduction to stomatal closure. The stomates are closed due to the inhibition of photosynthesis. Wills et al. (121) also reported reduced 
transpiration both in intact and excised shoots of corn, cotton and soybean. They found high moisture content in treated plants up to 24 hours after treatment, but this moisture content later dropped down.

Respiration as well as the activity of catalase, peroxidase, phenol oxidase, ascorbic acid oxidase and glycolic acid oxidase had been decreased by atrazine, according to Funderburk and Davis (43), in oats, soybean, bean, cotton, peanut and Johnsongrass.

The mode of action of atrazine and simazine in susceptible and resistant lines of corn, had been reported by Eastin et al. (33). G.T.112 RfRP was used as resistant and G.T.112 as the susceptible line. They found that glucose and sucrose supplied to the treated plants through a severed leaf tip protected the susceptible line from the toxic effect of atrazine and simazine. The oxygen uptake by excised roots of G.T.112 treated with atrazine gradually declined with the age until the death of the plant. Atrazine decreased root respiration in G.T.112 but had no effect in G.T.112 RfRP. Root respiration in untreated G.T.112 was higher than in untreated G.T.112 RfRP. Atrazine decreased leaf respiration in both lines.

As previously indicated, no work has been done to elucidate the effects of triazines on the nitrogen metabolism of plants. However, much work has been reported about the mode of action of 2,4-dichlorophenoxyacetic acid $(2,4-D)$ in plants. A review of the literature regarding the influence 
of 2,4-D on certain aspects of nitrogen metabolism of plants, therefore, appeared desirable.

Protein and free amino acids: In many instances application of 2,4-D to plants affected protein and free amino acids metabolism. In general, 2, 4-D increased protein and free amino acids in the stem and decreased these constituents in the leaves and roots.

The increase in protein content by $2,4-D$ has been reported by Sell et al. (94) in bean stem, by West et al. (119) in cucumber stem, by Basler and Nakazawa (10) in cotyledonous leaf tissue and by Dunham (32) in wheat and barley grains. The increases in protein content also were found by Freiberg and Clark (40) in the root and stem of soybean and by Payne et al. (82) in potato tubers. Sell et al. (94) showed that 2,4-D caused an increase in protein content due to the depletion of carbohydrate.

Sell et al. (94) demonstrated that 2,4-D increased arginine, histidine, isoleucine, leucine, phenylalanine, valine, lysine and methionine content in bean stem. Free amino acids were reduced by 2,4-D, according to Weller et al. (118), in roots and leaves of bean plant. One-half $1 \mathrm{~b}$. of 2,4-D per acre decreased the amount of 11 amino acids and increased glutamic acid content in potato tubers (82). Free amino acids were increased in the tops of potato and sugar beet plants and were decreased in bean tops when 2,4-D was applied to the foliage (44). 
Akers and Fang (1) exposed 2, 4-D treated bean plants to $\mathrm{C}^{14} \mathrm{O}_{2}$. They found greater incorporation of $\mathrm{C}^{14} \mathrm{O}_{2}$ into the aspartic and glutamic acids, but the amount and percentage of these amino acids were considerably smaller in the treated plants.

Ribonucleic acid: The increase in RNA content of 2, 4-D treated $t$ issues has been reported by many investigators. This increase has been shown by Rebstock et al. (86) in bean plants, by West et al. (119) in cucumber stem, by Basler and Nakazawa (10) in cotyledonous leaf tissue of young cotton seedlings and by Key and Hanson (62) in soybean seedlings.

The location of the nucleic acid within the cell components was altered by 2,4-D, according to Basler and Nakazawa (10). They found more RNA in the soluble protein and less RNA in the particulate protein. West et al. (120) showed a marked increase in the RNA content in the microsomal portion of the cytoplasm of cucumber tissue. Chrispeels and Hanson (23) reported doubling of RNA in both microsomal and soluble fractions obtained from 2,4-D treated soybean hypocotyl. According to Key and Hanson $(61,62)$, the incorporation of ADP-C 14 in RNA of soybean hypocotyl was enchanced by 2,4-D application. Low concentration of 2, 4-D was found to decrease RNA in cucumber tissue (119). 


\section{Chloroplast Structure}

A chloroplast, the site of photosynthesis, acts as energy capturing, storing and transferring device in photosynthesis. The grana containing chloroplasts of higher plants are lamellar. These lamallae are differentiated into non-pigmented stroma and the pigmented chlorophyll containing grana. The ultra-micro structure consists of lamellae. In the absence of chlorophyll, the lamellae are not formed (123). The photosynthetic pigment, the chlorophyll and carotenoids, are concentrated within the dense lamellae of the grana containing chloroplasts and in the lamellar chloroplasts (103).

Frey-Wyssling (41) proposed that a chloroplast consists of 20 to 30 parallel lipid layers. These layers are separated from the aqueous protein layer by macromolecular films of chlorophyll molecules. The hydrophillic porphyrin "head" of each chlorophyll molecule extends into the aqueous protein complex and the lipophillic phytol "tail" reaches into the lipid layer (41). It was further postulated that each fatty layer is $50 \mathrm{~A}$ thick and is separated from another by aqueous protein. As yet, no chemical analyses of these layers has been possible. The location of these layers has been assumed from the chemical reactions of the fixing agents and various strains with biological materials (107).

The concentrations of chlorophyll within the chloroplast vary in a variety of plant chloroplasts (127). Trurnit (107) suggested that the chlorophyll molecule lies at an angle of $35^{\circ}$ to $55^{\circ}$ within the lamellae. 
The precise composition and chemistry of the active chloroplast is still unknown. The gross analysis of isolated chloroplasts indicates that they consist of 35 to 55 per cent protein, 18 to 37 per cent lipids-mostly phospholipids--and 5 to 8 per cent inorganic materials on dry weight basis (126). The composition of lipid is not uniform in various plants, although galactolipids are present and linolenic acid predominates $(11,27$, 122). Nucleic acids - RNA and DNA - have been identified, with estimates from 0.3 to 3 per cent on dry weight basis $(15,83)$. The chloroplast pigment - the chlorophyll averages about 6 per cent and carotenoids 2 per cent on dry weight basis. The mean total phosphorus is 0.4 per cent on dry weight basis. This phosphorus includes inorganic phosphorus, phosphatides and nucleic acid phosphorus (124).

Cytochrome- $f$ and cytochrome- $b_{3}$ have been found in the chloroplasts by Hill (55). These two cytochromes together could make up as much as 20 per cent of total protein content of the chloroplasts (55). Small amounts of carbohydrate, mostly arabinose and galactose, have been found in chloroplasts (67).

In Euglena, the chloroplast chlorophylls constitute about 85 per cent chlorophyll a and 15 per cent chlorophyll b (125). The major carotenoids are $\beta$-carotene, lutein and neoxanthin. However, in Euglena, instead of lutein, 80 per cent of the carotenoids present were 
identified as antherxanthin, 11 per cent $\beta$-carotene and 7 per cent neoxanthin (63).

Synthesis of the polypeptide bond in chloroplast has been studied by Sissakin (98) using $\mathrm{c}^{14}$ and $\mathrm{s}^{35}$ isotopes. He concluded that peptide bond synthesis can be independently carried out by the chloroplasts as well as the mitochondria.

\section{Protein Synthesis}

Protein synthesis requires: 20 different Lamino acids, 20 different amino acid-activating enzymes, at least 20 separate kinds of soluble RNA (sRNA), energy source, divalent ions, a complex aligning mechanism containing some sort of genetically controlled code, and various additional enzymes for peptide bond formation, release of the complex protein from the "template" and reactivation of the SRNA.

\section{Results of many experiments suggested that} the mechanism of protein synthesis involves the following chemical steps:

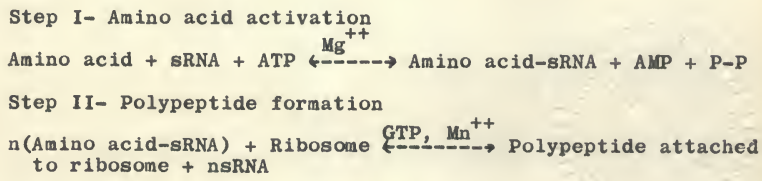


Amino acid activation: It is now well established that the enzyme responsible for the activation of amino acids occurs in the cells of many different kinds of plants, animals and microorganisms (24, 29, 30, 78).

This enzyme is specific and activates only L-amino acids and some analogues $(24,65,76,77,114)$. These enzymes have been purified from various sources.

The one end of amino acid attaches with enzyme and the carboxyl end esterifies with ADP. This linkage of carboxyl group to AMP has been supported by pyrophosphate exchange reactions $(30,31,57)$, by the synthesis of ATP from pyrophosphate and synthetic amino acid-AMP $(31,64)$ and by the transfer of $0_{2}^{18}$ from the amino acid carboxyl to the AMP phosphate $(12,59)$.

Soluble ribonucleic acid: The most obvious mechanism for specifying the order of amino acids in a forming polypeptide chain is by the sequential base-pairing of each sRNA molecule (with attached amino acid) with a particular sequence of bases in ribosomal RNA.

The X-ray diffraction pattern of total adapter or sRNA resembles the diffraction pattern of DNA (17). The observed orientation strongly confirms the doublehelical nature of sRNA. Recently, Spencer et al. (99) succeeded in crystallizing a sRNA from yeast, which they believe to be adapter RNA. On the basis of X-ray diffraction studies, they proposed that adapter RNA from yeast has completely regular Watson-Crick type base pairing. 
The sedimentation constant and molecular weight of sRNA from Escherlchia coli has been reported by various workers from 2.50 to $4.65 \mathrm{~s}$ and 15,000 to 50,000 respectively $(15,104)$. The molecular weight of about 24,000 indicates a chain length of about 67 mucleotides (17). This suggested that the structure consists of a single polynucleotide chain with a hair pin bend approximately in the middle.

A11 adapter RNA have the terminal sequence of amino acid-adenylic acid-cytidylic acid-cytidylic acid on one end and guanine on the other. The sequence of nucleotides in between the two terminal groups is not known. With the two free nucleotides on the amino acid end, the third nucleotide (cytidylic acid), could make a base pair of the Watson-Crick type with guanine from the other end of the adapter RNA. The three unpaired nucleotides in the bend serve as the coding trinucleotide sequence which is presumed to react by specific base pairing with messenger RNA (mRNA) template. The unpaired A-C grouping on the end, carrying the amino acid may give amino acids on adjacently adsorbed adapter RNA sufficlent freedom of movement to make contact.

Polypeptide formation: The theory of how amino acids are ordered on ribosomes was proposed by Crick (26). The amino acids linked with specific adapter RNA are transferred to the ribosome where the adapter RNAS' are joined by hydrogen bonds to complementary sites on an RNA-template 
called mRNA and the amino acids are placed in the proper juxtaposition for polypeptide synthesis. The amino acids are added sequentially to the N-terminal end of the growing polypeptide chain on the surface of ribosome (115, 128) .

The transfer of amino acid-sRNA to the reticulocyte microsome requires GTP, ATP, an ATP-generating system and an enzyme fraction (58). This enzyme was found to consist of both a heat-stable and heat-labile fraction (49). The heat-stable factor can be replaced by glutathione (73) and increased concentration of ATP and GTP (69). Similar requirements for the transfer reactions have been noted with pea ribosomes (115). Under such conditions, pea ribosomes will catalyze the conversion of amino acid-sRNA into "soluble protein" at considerably greater rates than are obtained with an equivalent quantity of free amino acids (116). This finding strongly supports the idea that sRNA-bound amino acids are intermediates in protein synthesis. The enzyme responsible for the transfer of amino acids from sRNA to ribosome-bound polypeptide has been partially purified $(13,69,73,117)$.

Messenger ribonucleic acid: The template for protein synthesis called mRNA, is separable from the ribosome (115). Zubay (131) assumed that mRNA, when active, exists in the form of a single polynucleotide chain with no intra-or intermolecular hydrogen bonding. 
Zamecnik (129) proposed a template structure. In his model, the bases of two molecules interact with the polypeptide chain in the completely extended configuration producing a hydrogen-bonded, stepladder-11ke structure analogous to the extended beta-configuration in protein. This is accompanied by orienting the polynucleotide chain of the mRNA in such a way that all the bases are situated on one side, and phosphate groups on the other. The three alleged coding nucleotides in the bend of the adapter RNA adopt a similar extended configuration. The translation distance per three nucleotides for extended mRNA would be 20 to $40 \AA$, which is very nearly the distance of close approach of adjacent adapter RNA double helices. Amino acids on adjacent adapter molecules could not interact unless provided with flexible extension. The postulated A-C terminal grouping of the RNA provides the minimum number of unpaired nucleotides to give the necessary reach.

The sequence of nucleotides in the synthetic mRNA had been related to the sequence of amino acids in the product polypeptide chain. Messenger RNA is read starting from the end with an unesterified $3^{\prime}-$ hydroxyl group (110).

Ribosomes: The general structure and amino acid composition of ribosomes from animals, plants and microorganisms are the same $(20,87,108)$. Ribosomes are spherical structures with a diameter of 200-300 A . The 
spherical ribosomes generally observed in extracts of $\underline{E}$.coli, have a sedimentation constant of $70 \mathrm{~S}$ and molecular weight of 2,600,000 (106). The 70S ribosome occurs in the presence of approximately $10^{-3_{M}}$ magnesium ion. At higher concentrations two 70s particles dimerize to form one 100s particle. The 70s ribosomes from $\underline{E} \cdot \underline{\text { coli }}$ are composed of two ribonucleoprotein sub-units, $30 \mathrm{~S}$ and 50s, with a molecular weight of $0.9 \times 10^{6}$ and $1.5 \times 10^{6}$, respectively (106). Each sub-unit is constituted by dry weight of about two-thirds RNA and one-third protein.

Both $50 \mathrm{~S}$ and $30 \mathrm{~S}$ particles are required in protein-stimulated polypeptide synthesis in vitro $(68,105)$. Which of the larger particles are active in protein synthesis is not known $(88,105)$, but at present it seems likely that $70 \mathrm{~S}$ ribosome is the smallest potentially effective unit. A significant amount of ribosomal RNA may be located inside the 70 S ribosome (97). Zubay (131) described some of the important properties of ribosomes.

1. Ribosomes in the process of protein synthesis do not dissociate as readily into their respective $50 \mathrm{~S}$ and 30 sub-units as do these ribosome which are inactive $(68,105)$.

2. mRNA is dissociated from the ribosome and ribosomes may associate more than one mRNA with varying molecular weight $(74,75)$.

3. The life time of the ribosome in bacterial cells is much greater than that of the mRNA $(60)$.

4. The 30S sub-unit and the 70 s particle have been shown to form a complex with synthetic mRNA under conditions where the 50 s sub-unit does not $(80)$. 
5. The 30S sub-unit in E.coli contains a latent ribonuclease.

The size of ribosomes must accomodate mRAS'

of various sizes. In most cases, mRNA molecule would be too large for the entire molecule to be in direct contact with the ribosome simultaneously. Probably one part of mRNA is bound at one time. Adjacently adsorbed adapters might, for greater stabilization, be adsorbed to the outer surface of the $50 \mathrm{~s}$ particle, and the polypeptide synthesis thus would be more closely associated with 50S ribosome. Zubay (131) gave the function of ribosomes in his model as to provide a "stabilizing surface" for maintaining the mRNA in a configuration that would be thermodynamically unstable in a solution and for maintaining the reacting adapter molecules in parallel register.

Considering the size of ribosomes and the length of mRNA, the idea of polyribosome or polysome emerged recently. Polyribosomes are clusters of ribosomes held together by RNA. Polysomes were first characterized in the rabbit reticulocyte (112). According to this idea, polysomes rather than the single ribosomes are active units for protein synthesis $(46,112,113)$.

Release of completed polypeptide from ribosome: The existence of a separate reaction for the release of a completed polypeptide chain from ribosomes is clearly indicated by the observation that both pea ribosomes (117) and reticulocyte ribosomes (13) will convert amino 
acid bound to sRNA into "soluble protein" in the presence of an unfractionated cell extract, but not in the presence of the purified "transfer enzyme". Release of the completed polypeptide chain is obtained only upon the addition of a second protein. This release also requires the presence of ATP and a divalent cation $(53,117)$. 


\section{MATERIALS AND METHODS}

In this investigation, Seminole variety of oats (Avena sativa L.) was the experimental material. This plant is susceptible to simazine and has been extensively used to assess the toxicity of simazine in soil.

\section{Planting in sand Culture}

Uniform seeds were selected and treated with Arasan-75 and Captan-75 (1:1) Pungicide. Oats seed were planted in sand in 4-inch paper cups. HoaglandArnon complete nutrient solution (56) was added each day. Simazine at the rates of $0,0.5$ and $2.01 \mathrm{bs}$. active ingredient (AI) per acre was used pre-emergence in these experiments. The calculated amount of simazine was dispersed in nutrient solution and applied to soil after planting.

The seeds were germinated and grown for 12 days in a growth chamber with controlled temperature, photoperiod and light intensity. The day and night temperatures were maintained at $72^{\circ} \mathrm{F}$ and $65^{\circ} \mathrm{F}$, respectively. The photoperiod was adjusted to 12-hour day and light intensity was maintained at 1,500 foot candle. A different set of plants was grown for each experiment. 
Fresh and Dry Weights

Four plant samples per simazine treatment of $0,0.5$ and $2.0 \mathrm{lbs}$. AI per acre were collected at two-day intervals starting six days after treatment. Each sample consisted of all plant parts above the soil surface and was washed with deionized water immediately after harvest and blotted to dryness. The samples were dried for 24 hours in an oven at $85^{\circ} \mathrm{C}$. After cooling of the samples, dry weights were determined. Fresh and dry weights were calculated on a per plant basis.

\section{Total Protein}

The total protein content of shoot tissue of plants grown in sand treated with simazine at $0,0.5$ and 2.0 lbs. AI per acre was determined in four replications. Samples were collected at two-day intervals, starting six days after treatment.

The plants were harvested, washed, dried and cut into smaller pieces. These pieces included in a given sample were transferred into a scored beaker to which deionized water was added to a total volume of $70 \mathrm{ml}$. The tissue was homogenized in an omnimixer at $0^{\circ} \mathrm{C}$. The homogenate was filtered through a four-layer cheese cloth and centrifuged at $400 \mathrm{Xg}$ to remove cell debris. The decanted supernatant was used for protein determination. 
The protein was precipitated by 10 per cent cold trichloroacetic acid (TCA). The chlorophyll and lipid were removed from the pellet by washing several times with undiluted acetone. The protein pellet was dissolved in $0.01 \mathrm{M}$ sodium hydroxide (NaOH). The quantity of protein in the tissue was determined by the method of Lowry et al. (66). The standard curve for protein estimation was prepared for bovine serum albumin (BSA).

To the protein aliquot, $5 \mathrm{ml}$ of 4 per cent sodium carbonate, 4 per cent sodium tartrate and 2 per cent copper sulfate mixture were added. After one hour, phenol reagent was added and mixed thoroughly. The volume was made to $10 \mathrm{ml}$ and after 30 minutes the optical density of the sample was read on Beckman DB spectrophotometer at $750 \mathrm{~m} \mu$ wavelength.

\section{Total Ribonucleic Acid}

Total RNA content of plants grown in sand treated with $0,0.5$ and 2.0 lbs. simazine per acre was determined by the method of Ogur and Rosen (79). The experiment was replicated four times. Samples were collected at two-day intervals starting six days after treatment.

The procedure for the collection of samples and homogenization was similar to that used for protein determination. The supernatant after removal of cell debris was used for the precipitation of total RNA. 
The RNA was precipitated by 1 N perchloric acid at $0^{\circ} \mathrm{C}$. The chlorophyll and lipid were removed from RNA pellets by several washings with a mixture of cold ethanol, ether and chloroform $(2: 2: 1 \mathrm{~V} / \mathrm{V})$. The RNA in the pellet was hydrolyzed in $0.5 \mathrm{M} \mathrm{NaOH}$. After complete hydrolysis of RNA, the pH of the hydrolyzate was adjusted to 7.0 and 2.0. Protein precipitated at these $\mathrm{pH}$ levels and was removed by centrifugation. The absorption spectrum of the samples was from 320 to $220 \mathrm{~m} \mu$ wavelength, respectively. The total RNA was calculated by the following equation:

$$
\begin{aligned}
\mu \mathrm{g} \text { of RNA }= & \text { O.D. at } 260-0 . D \text {. at } 290 \mathrm{~m} \mu \times 57 \\
& \text { X dilution X volume of RNA solution }
\end{aligned}
$$

\section{Chlorophyll}

Total chlorophy11, chlorophyll a and chlorophyll b of plants grown in sand treated with 0 and 2.0 1bs. of simazine per acre was determined by the method of the Association of Official Agricultural Chemists (9). In all, four samples in three replications were collected at two-day intervals starting six days after treatment. The seedlings were harvested and weighed. Tissue was chopped into smaller pieces and mixed with $0.1 \mathrm{gram}$ of calcium carbonate. The tissue was homogenized in 85 per cent acetone. The homogenate was filtered and the residue was washed several times with 85 per cent acetone to remove chlorophyll. An aliquot of $20 \mathrm{ml}$ was transferred 
to a separatory funnel containing ether. In this way, all the acetone was removed from the extract. The ether extract was washed several times with water. This chlorophyll extract was dried on anhydrous sodium sulfate. The dried extract was diluted so that the absorbance at $652 \mathrm{~m} \mu$ did not exceed 0.8 . The absorbance of chlorophyll extract was read on spectrophotometer at 652 and $634.5 \mathrm{~m} \mu$ with $0.05 \mathrm{~mm}$ slit width. Total chlorophyll, chlorophyll a and chlorophyll b were calculated by the following equation:

$$
\begin{aligned}
& \text { Total chlorophyll (mg per liter) }=7.12 \mathrm{~A} 652+16.8 \mathrm{~A} 634.5 \\
& \text { Chlorophyll a (mg per liter) }=9.93 \mathrm{~A} 652-0.777 \mathrm{A634.5} \\
& \text { Chlorophyll b (mg per liter) }=17.6 \mathrm{~A} 634.5-2.81 \mathrm{~A} 652
\end{aligned}
$$

Where $A=$ Absorbance

Free Amino Acids

Triplicate samples of 1.5 grams fresh tissue from sand treatments of 0 and 2.0 lbs. of simazine per acre were collected at two-day intervals starting six days after treatment. The tissue was homogenized in 80 per cent hot ethanol in an omnimixer. The homogenate was centrifuged at $800 \mathrm{Xg}$. The sediment was washed with ethanol and centrifuged. The supernatants were pooled and concentrated by passing a stream of air throug them. The volume was made up to $3 \mathrm{ml}$, centrifuged and the supernatant used for chromatography.

A measured volume of amino acid standard and of sample was chromatographed on Whatman number 1 filter 
paper. The amino acids were separated by twodimensional, ascending paper chromatography. The solvents used were n-butanol, acetic acid and water $(25: 6: 25 \mathrm{~V} / \mathrm{V})$ and phenol and water $(10: 2 \mathrm{~V} / \mathrm{V})$. Color was developed by 0.3 per cent ninhydrin in 95 per cent ethanol sprays. The Rf value for each spot was calculated. The amino acids in the sample were identified with the help of Rf values of standards.

A standard curve for L-leucine was prepared. For this, a different amount of leucine was chromatographed separately on Whatman number 1 filter paper. After drying of these spots, color was developed by ninhydrin spray. These spots were cut and eluted in $3 \mathrm{ml}$ of 80 per cent ethanol and the optical density at $570 \mathrm{~m} \mu$ wavelength was read on spectrophotometer. The standard curve was prepared by plotting concentration of L-leucine on $\mathrm{X}$-axis and optical density on $\mathrm{Y}$-axis.

The identified spots of the free amino acids of sample were cut and eluted in 80 per cent ethanol. The optical density of these spots was recorded. The concentration of each amino acid present in the sample was calculated from standard curve and expressed as L-leucine per gram fresh tissue.

\section{Particulate Proteins}

Triplicate samples of plants from treatments of 0 and 2.0 lbs. of simazine per acre were collected at two-day intervals starting six days after treatment. 
The weighed and washed tissue was homogenized in $0.5 \mathrm{M}$ glucose, $0.02 \mathrm{M}$ magnesium chloride and $0.02 \mathrm{M}$ phosphate buffer at $\mathrm{pH} 7,0$.

The homogenate was filtered through a fourlayer cheese cloth. The filterate was centrifuged at $2,000 \mathrm{Xg}$ for $10 \mathrm{minutes}$ to sediment chloroplasts. The supernatant fraction was centrifuged at $15,000 \mathrm{Xg}$ for 25 minutes to sediment mitochondria. Microsomes were sedimented by centrifugation of the supernatant at $105,000 \mathrm{xg}$ for two hours in ultra-centrifuge. The supernatant fraction obtained after isolation of microsomes was used for the estimation of soluble protein. Each sediment was suspended in the homogenization mixture.

The protein in each fraction was precipitated by 5 per cent cold TCA. The chlorophyll and lipids were removed by washing the protein pellet several times with undiluted acetone. The protein was dissolved in $0.01 \mathrm{M} \mathrm{NaOH}$ and determined by the method of Lowry et al. (66).

\section{Radioisotope Experiments}

Incorporation of $\mathrm{C}^{14}$-leucine in protein: The radioactive leucine was obtained from Schwarz BioResearch Inc. with more than 99.5 per cent purity. The isotope was dissolved in $0.01 \mathrm{~N} H \mathrm{HCl}$ and its specific activity was 20.1 millicounts per mM. 
Incorporation of $\mathrm{C}^{14}$-leucine in total and chloroplast proteins of check and simazine treated plant tissue

Duplicate samples of plants from treatments of

0 and $2.0 \mathrm{lbs}$. of simazine per acre were collected six and ten days after treatment. The weighed tissue was chopped into one centimeter sections. These sections were incubated at $23^{\circ} \mathrm{C}$ for 1.5 hours in $0.002 \mathrm{M}$ potassium citrate, 0.001 ammonium biphosphate, 0.003 M sucrose and $5 \mu \mathrm{c} \mathrm{C}^{14}-$ leucine. After incubation, the $t$ issue was washed several times with water and leucine to remove any absorbed free $c^{14}$-leucine. The tissue was homogenized in 10 per cent sucrose, $5 \times 10^{-3} \underline{M} \operatorname{Tr}$ is and $10^{-4} \underline{M} \mathrm{MgCl}_{2}$ at $0^{\circ} \mathrm{C}$.

The homogenate was filtered through a four-layer cheese cloth. This filterate was used for the precipitation of total protein. The chloroplasts in the cleared homogenate were sedimented at $2,000 \mathrm{Xg}$ for 10 minutes at $0^{\circ} \mathrm{C}$. The chloroplasts were suspended in the homogenization media.

The protein was precipitated by $1 \underline{M}$ perchloric acid. The protein pellets were washed several times with undiluted acetone to remove chlorophyll and lipid. These pellets were washed twice with $1.5 \times 10^{-5} \underline{M}$ leucine in $0.2 M$ perchloric acid to remove radioactivity bound to the protein other than peptide linkage. The protein was dissolved in $0.01 \mathrm{M} \mathrm{NaOH}$ and this solution was transferred to planchets. Planchets were dried and the radioactivity was counted with a Nuclear Chicago gas flow counter, using Q-gas at 4 1bs. pressure per square 
inch. The number of counts per minute per gram fresh tissue was calculated.

Incorporation of $\mathrm{c}^{14}$-leucine in total and chloroplast protein of tissues incubated with and without simazine

The procedure followed in this experiment was the same as that followed in the previous experiment except simazine at 1 p.p.m. concentration was added in the incubation mixture. The incubation period was increased to three hours and the quantity of $\mathrm{C}^{14}$-leucine added in the incubation mixture was reduced to $3 \mu \mathrm{c}$.

Incorporation of $\mathrm{C}^{14}$-leucine in the total and chloroplast proteins of 10-day old check and simazine treated plant tissue incubated with and without glucose solution

The procedure used in this experiment was the same as has been described earlier. Glucose at the concentration of 6 per cent was added in the incubation mixture. The incubation time was three hours and the amount of radioactive leucine used in incubation was $1.5 \mu \mathrm{c}$.

Incorporation of $\mathrm{c}^{14}$-leucine in the total protein of 10-day old check and simazine treated tissue grown in 11ght and dark

In this experiment, duplicate samples of fresh tissues were collected from the following treatments:

1. 0 lbs. of simazine per acre and plants grown in light

2. 0 lbs. of simazine per acre and plants grown in dark 
3. $2.01 \mathrm{bs}$. of simazine per acre and plants grown in light

4. 2.0 lbs. of simazine per acre and plants grown in dark

The procedure for sample preparation, protein precipitation and radioactivity counting was the same as that mentioned earlier.

Incorporation of $\mathrm{p}^{32}$ in ribosomal RNA: Oat seedlings for this experiment were grown in water culture using Hoagland-Arnon complete nutrient solution. These seedlings were grown in a room with constant temperature and light. The calculated amount of simazine was added in the treated containers. The seedlings were grown for nine days. On the ninth day, the nutrient solution of the containers was replaced by the nutrient solution containing $\mathrm{p}^{32}$. On the tenth day, shoots were harvested and used for determination.

\section{Determination}

The weighed and washed $t$ issue was homogenized in a mixture of 5 per cent sucrose, $5 \times 10^{-3} \underline{M}$ Tris and $10^{-3} \underline{M} \mathrm{MgCl}_{2}$. The homogenate was filtered through a four-layer cheese cloth. The filterate was centrifuged at $15,000 \mathrm{Xg}$ for 20 minutes to remove the cell walls, chloroplasts and mitochondria. The volume of the supernatant fraction was reduced to $10 \mathrm{ml}$ by lypholyzation. This extract was made at a concentration of 0.5 per cent deoxycholate (DOC). 
A density gradient from 30 per cent to 5 per cent sucrose was prepared. The extract was added on the top of the density gradient and was centrifuged in a swinging bucket, number 25.1, at 23,000 r.p.m. in ultra-centrifuge for two hours. Two $\mathrm{ml}$ fractions were collected in which RNA was precipitated by $1 \underline{M}$ perchloric acid and defatted by ethanol, ether and chloroform mixture. The RNA was hydrolyzed in $0.5 \mathrm{~N}$ $\mathrm{NaOH}$. The $\mathrm{pH}$ of the hydrolyzate was adjusted to 7.0 and the absorption at 260 and $290 \mathrm{~m} \mu$ was read on spectrophotometer. The radioactivity in these fractions was counted with a Nuclear Chicago gas flow counter, using Q-gas at 4 lbs. pressure per square inch.

\section{STATISTICAL ANALYSIS}

The data from different experiments were analyzed in factorial randomized design as described by Steel and Torrie (102). 


\section{EXPER IMENTAL RESULTS}

The present investigation was conducted to gain a better understanding of the influence of simazine on the physiology of plants. As mentioned earlier, the Seminole variety of oats was the experimental material in which the influence of this herbicide on nitrogen metabolism was studied in detail.

\section{Toxicity Symptoms}

The seed planted in sand and treated with simazine germinated and the seedlings emerged normally on the fourth day. The development of phytotoxicity symptoms are shown in Figures $1,2,3,4$ and 5 . No distinct symptoms of phytotoxicity appeared before the yellowing of the entire leaf blade six days after treatment. The leaf tips became white about eight days after treatment and the leaves started drying two days later. The plants become completely dessicated 14 days after simazine application.

\section{Fresh and Dry Weights}

As indicated by the data in Table 1 , the rate of 0.5 lbs. of simazine slightly increased fresh weight of plants in the sample analyzed six days after treatment. In later samples, the fresh weight of plants from this treatment decreased. This decrease was as 


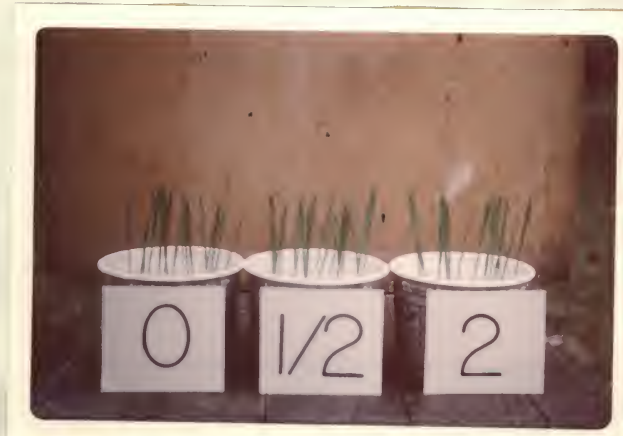

Fig. 1. Influence of different rates of simazine on the growth of oat plants, five days after treatment $(0,1 / 2$ and 2 indicate $0,0.5$ and 2.0 lbs. simazine per acre, respectively). 


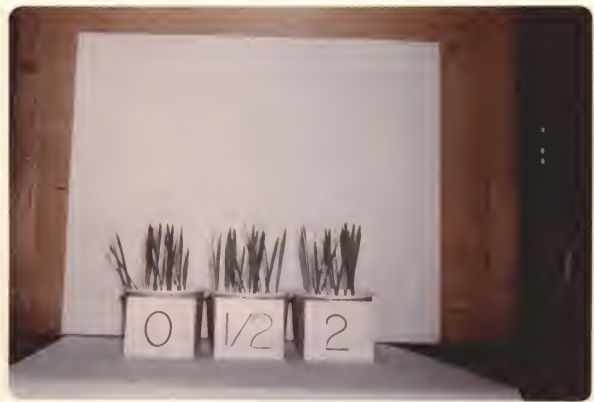

Fig. 2. Influence of different rates of simazine on the growth of oat plants, $81 x$ days after treatment $(0,1 / 2$ and 2 indicate $0,0.5$ and 2.0 lbs. simazine per acre, respectively). 


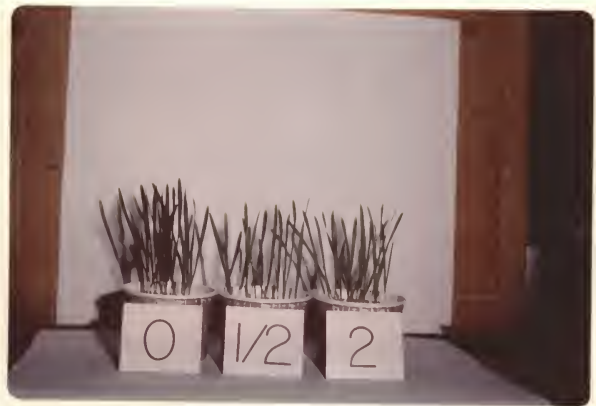

Fig. 3. Influence of different rates of simazine on the growth of oat plants, eight days after treatment $(0,1 / 2$ and 2 indicate $0,0.5$ and 2.0 lbs. simazine per acre, respectively). 


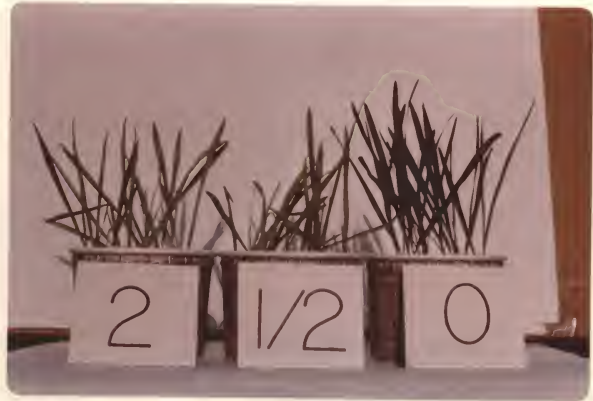

Fig. 4. Influence of different rates of simazine on the growth of oat plants, 10 days after treatment $(0,1 / 2$ and 2 indicate $0,0.5$ and 2.0 lbs. simazine per acre, respectively). 


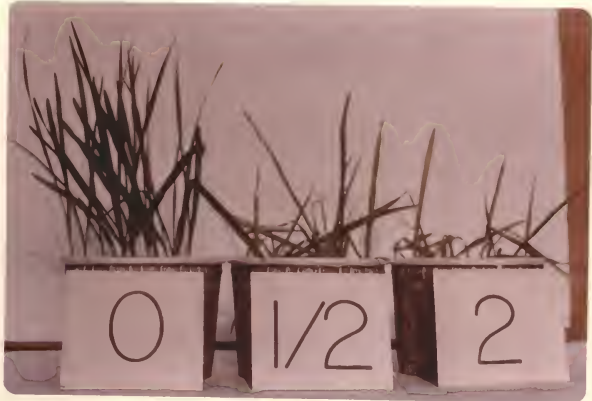

Fig. 5. Influence of different rates of simazine on the growth of oat plants, 13 days after treatment $(0,1 / 2$ and 2 indicate $0,0.5$ and 2.0 lbs. simazine per acre, respectively). 


\section{TABLE 1}

A COMPARISON OF THE CHANGES OF FRESH AND DRY WEIGHTS OF OAT PLANTS TREATED WITH SIMAZINE

Days after planting Rate of simazine
and simazine application

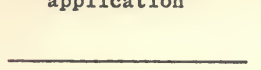

6

8

10

12

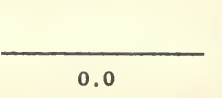

0.5

2.0

0.0

0.5
Fresh and dry weights $(\mathrm{mgm} / \mathrm{p})^{1}$

\begin{tabular}{ccc}
\hline $\begin{array}{c}\text { Fresh } \\
\text { Weight }\end{array}$ & & $\begin{array}{c}\text { Dry } \\
\text { Weight }\end{array}$ \\
109.50 & & 9.08 \\
117.80 & & 9.09 \\
108.20 & & 8.33 \\
\hline
\end{tabular}

13.57

8.75

8.27

$\begin{array}{lll}2.0 & 99.30 & 8.27\end{array}$

177.69

16.49

105.75

9.66

107.93

9.28

223. 24

20.64

71.90

8.91

2.0

102.50

10.72

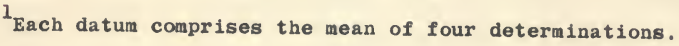


much as 67 per cent in the sample collected 12 days after simazine application.

No marked differences in the fresh weight were found in the $2.0 \mathrm{lbs}$. per acre treatment when the samples were collected six days after treatment. However, the fresh weight of plants from this treatment decreased in later samples. The maximum decrease to the extent of 54 per cent in the fresh weight of this treatment was found in the last sample. The fresh weight of $0 \mathrm{lb}$. treatment increased in the subsequent samples, but the fresh weight of 2.0 lbs. treatment was about the same throughout the growth period.

Table 1 shows that the rate of change in dry weight due to simazine treatment is approximately the same as fresh weight. No significant differences were found between the dry weight of plants from 0 and $0.5 \mathrm{lb}$. of simazine treatments in the sample collected six days after treatment. Differences in the dry weight due to simazine treatment occurred in the samples collected 8,10 and 12 days after simazine application.

The statistical analysis of fresh and dry weight (Table 3) shows highly significant differences among treatments, sampling intervals and interaction.

\section{Total Protein}

The changes in protein concentration of oat shoots as the result of simazine treatment are shown in Table 2. The rate of change was the same on both fresh 


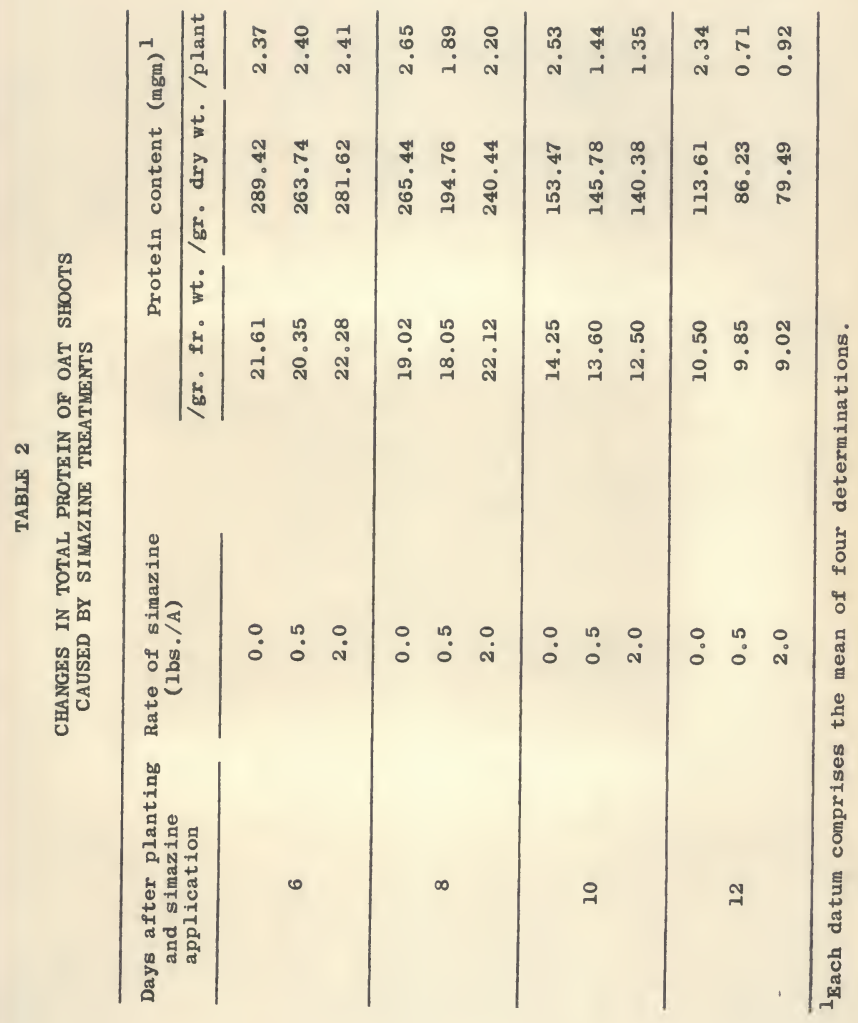




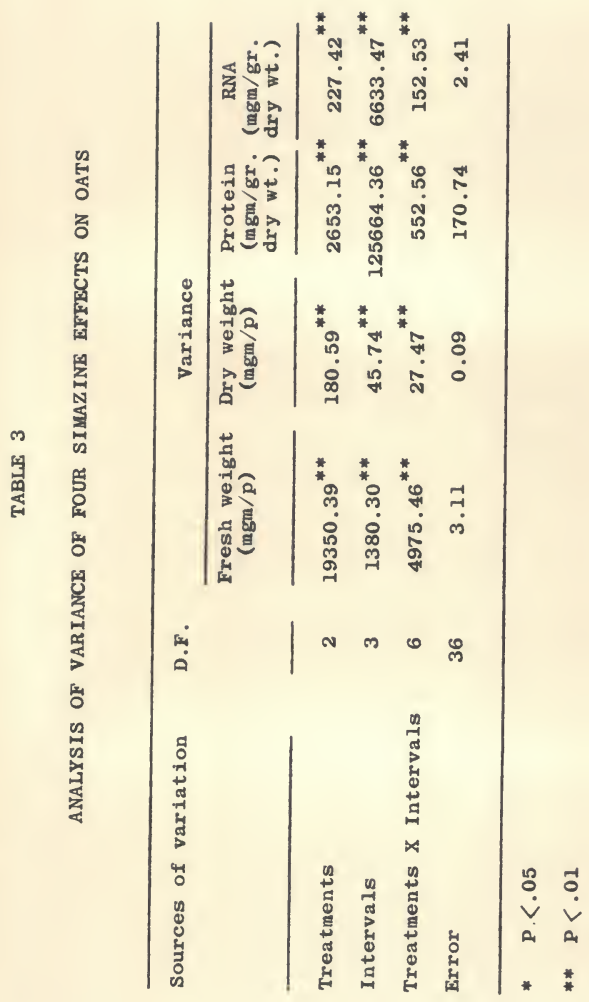


and dry weight basis. The only observed difference in these two results was that the protein content per gram fresh tissue in the samples collected six and eight days after simazine application was more in the plants from 2.0 lbs. treatment than 0 1b. rate. The protein content decreased in the shoots receiving the $0.51 \mathrm{~b}$. treatment in all samples analyzed $6,8,10$ and 12 days after treatment. The protein concentration in the last two samples ( 2.0 lbs. treatment) decreased more than 0.5 lb. treatment.

The differences in protein contents of plants in different treatments, sampling intervals and interaction were statistically significant at 1 per cent probability level (Table 3 ).

Total Ribonucleic Acid

Table 4 indicates an increased RNA content in fresh tissue of plants from 2.0 lbs. simazine treatment In the samples analyzed six and eight days after simazine application. In the samples analyzed 10 and 12 days after treatment, the RNA concentration in this treatment decreased 40 and 70 per cent, respectively. The 0.5 lb. treatment decreased RNA content in all four samples. However, in the last two samples RNA was more affected by 2.0 lbs. treatment than 0.5 lb. The differences in the results calculated on dry weight basis and fresh weight basis were that the concentration of RNA per gram dry tissue in 2.0 lbs. treatment decreased 


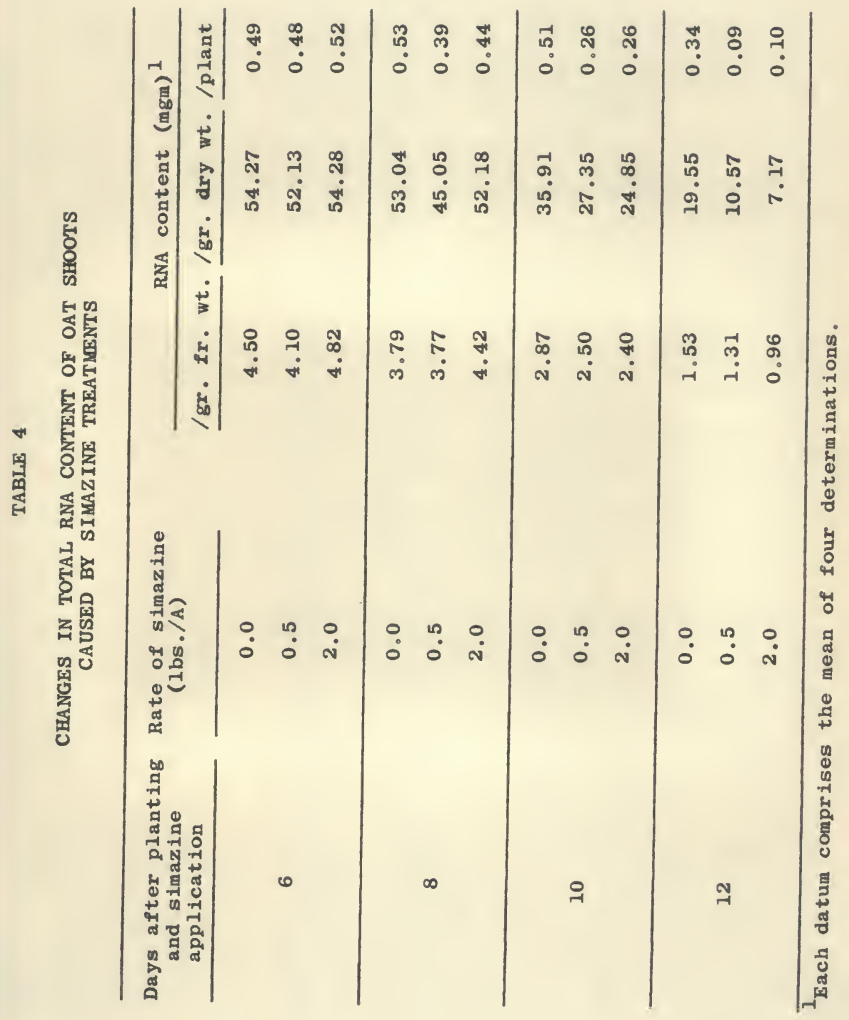


in first and second samples also.

The per plant RNA content of plants treated with 2.0 lbs. simazine was slightly increased in the first sample. A marked decrease in RNA content occurred in both levels of simazine in the samples analyzed 8,10 and 12 days after the application of simazine. The differences in the RNA content of treatments, sampling intervals and interaction were highly significant (Table 3 ).

\section{Chlorophylls}

The results of chlorophyll determination in the plants grown in sand treated with 0 and 2.0 lbs. of simazine per acre are listed in Table 5. In general, a rise occurred in total chlorophyll and chlorophyll a contents per gram fresh tissue in plants growing in the 0 rate of simazine application up to eight days of the growth period. These chlorophylls decreased in later samples. Chlorophyll b increased throughout the growth period. On the other hand, gradual increase in per plant total chlorophyll, chlorophyll a and chlorophyll b contents occurred in the subsequent samples.

These results clearly indicate that all chlorophylls had been affected by simazine treatment. In the earlier samples, chlorophyll b was not affected to the same extent as chlorophyll a. However, in the last sample, chlorophyll a and chlorophyll b per gram fresh tissue decreased as much as 67 and 74 per cent, 
号

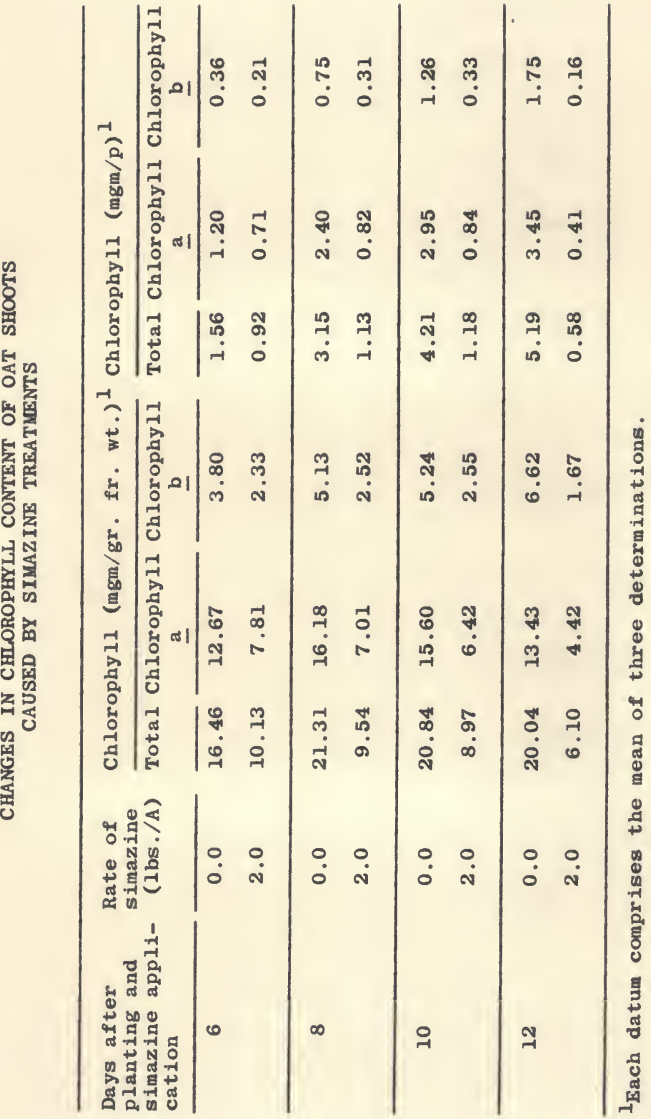


respectively. This determination shows that the decrease in chlorophyll b was greater than in chlorophyll a in the sample collected 12 days after treatment.

The statistical analysis of these data shows that the differences in chlorophyll a and chlorophyll b due to simazine treatment are highly significant (Table 6). The variations among the sampling intervals, chlorophylls and various interactions except one were found significant at 1 per cent probability level.

Alcohol-Soluble Amino Acids

Free amino acids in the shoots of plants grown in sand treated with 0 and 2.0 lbs. of simazine per acre $6,8,10$ and 12 days after treatment are shown in Table 7. The concentration of each amino acid is given in terms of L-leucine.

In general, the concentrations of free amino acids six and eight days after simazine application were higher in plants from 0 lb. than 2.0 lbs. simazine treatment. An opposite result was found in the last two samples where the concentrations of free amino acids increased in the plants subjected to the 2.0 lbs. treatment.

More specifically, in the first sample the concentrations of aspartic acid, serine, threonine, alanine and histidine decreased and the concentration of glutamic acid increased in the plants from $2.0 \mathrm{lbs}$. simazine treatment. No differences in lysine, phenylalanine and leucine contents were found between 0 and 


\section{TABLE 6}

\section{ANALYSIS OF VARIANCE OF CHLOROPHYLL CONTENT OF OATS}

\begin{tabular}{|c|c|c|}
\hline Sources of variation & D.F. & Variance \\
\hline & & $\begin{array}{l}\text { Chlor ophy } 11 \\
(\mathrm{mgm} / \mathrm{l} / \mathrm{p})\end{array}$ \\
\hline Treatments & 1 & $20.01^{* *}$ \\
\hline Intervals & 3 & $1.63^{* *}$ \\
\hline Chlorophylls & 1 & $10.97^{* *}$ \\
\hline Tr. X Intervals & 3 & $2.12^{* *}$ \\
\hline Tr. X Chlorophylls & 1 & $3.17^{* *}$ \\
\hline Intervals X Chlorophylls & 3 & $0.12^{*}$ \\
\hline Tr. X Intervals X Chlorophy 11s & 3 & $0.17^{\star *}$ \\
\hline Error & 32 & 0.03 \\
\hline$* \quad \mathrm{P}<.05$ & & \\
\hline$\star * \mathrm{p}<.01$ & & \\
\hline
\end{tabular}




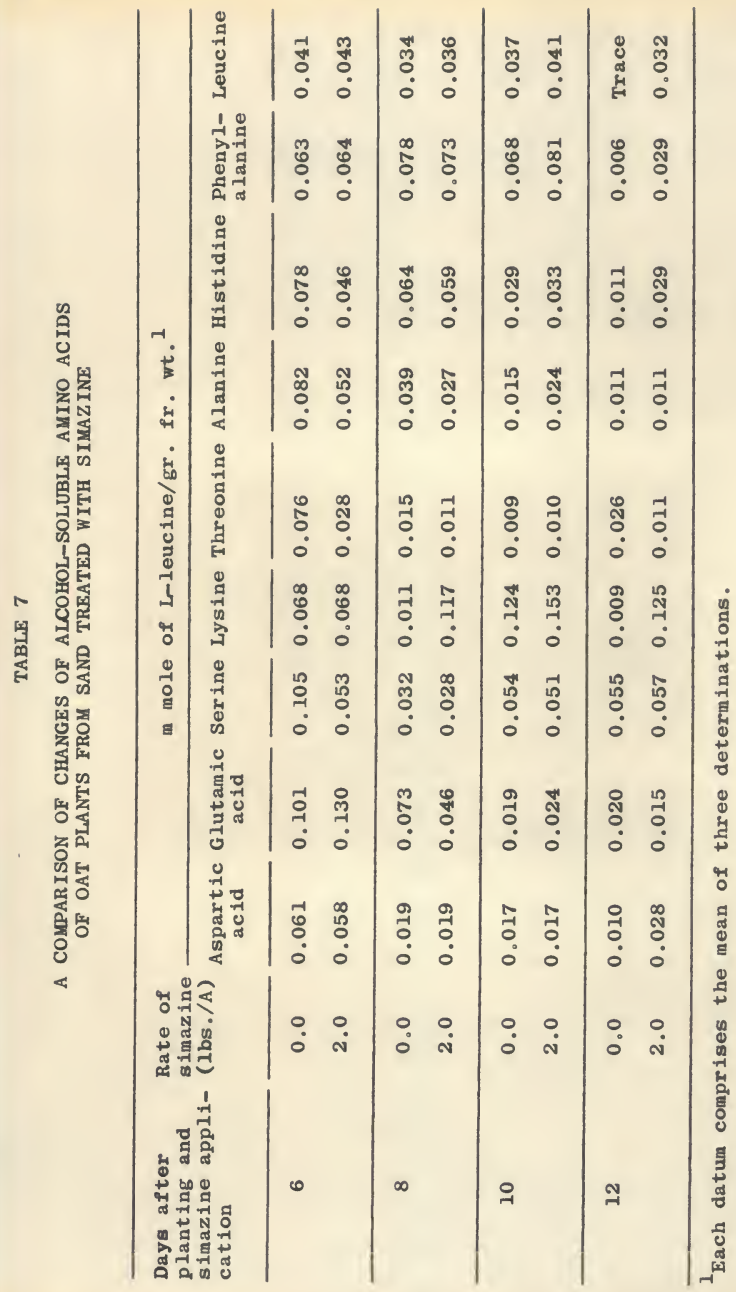


2.0 lbs. treatment. The concentration of all the mentioned amino acids, except lysine, decreased in plants eight days after treatment with 2.0 lbs. of simazine.

In the last two samples, concentrations of all the reported free amino acids increased in plants from the 2.0 lbs. treatment with this increase being most pronounced in lysine.

The statistical analysis (Table 8) indicated that the differences among the treatments, sampling intervals, amino acids and interactions are highly significant.

\section{Particulate Proteins}

The changes in particulate proteins of plants grown in sand treated with 0 and 2.0 lbs. of simazine per acre are shown in Table 9. Chloroplast proteins were decreased 28 per cent by the sixth day after receiving the $2.0 \mathrm{lbs}$. treatment. In contrast to chloroplast proteins in this sample, the concentrations of mitochondrial, ribosomal and cytoplasmic proteins were increased by simazine treatment.

The chloroplast proteins of plants from $2.01 \mathrm{bs}$. of simazine decreased to about half in the sample collected eight days after treatment. Simazine also caused increased concentrations of mitochondrial and ribosomal proteins. 
TABLE 8

ANALYSIS OF VARIANCE OF CONTENTS OF FREE AMINO ACIDS OF OATS

\begin{tabular}{|c|c|c|}
\hline Sources of variation & D.F。 & Variance \\
\hline & & $\begin{array}{c}\text { Amino acids } \\
(\mathrm{m} \text { mole/gr } \\
\mathrm{fr} \text {. wt.) }\end{array}$ \\
\hline Treatments & 1 & $0.0009^{* *}$ \\
\hline Intervals & 3 & $0.0106^{* *}$ \\
\hline Amino acids & 8 & $0.0061^{* *}$ \\
\hline Tr. $X$ Intervals & 3 & $0.0023^{* *}$ \\
\hline Tr. X Amino acids & 8 & $0.0021 * *$ \\
\hline Intervals $X$ Amino acids & 24 & $0.0020^{* *}$ \\
\hline Tr. $X$ Intervals $X$ Amino acids & 24 & $0.0005^{* *}$ \\
\hline Error & 72 & 0.000002 \\
\hline$* \quad \mathrm{P}<.05$ & & \\
\hline$* * \quad \mathrm{P}<.01$ & & \\
\hline
\end{tabular}




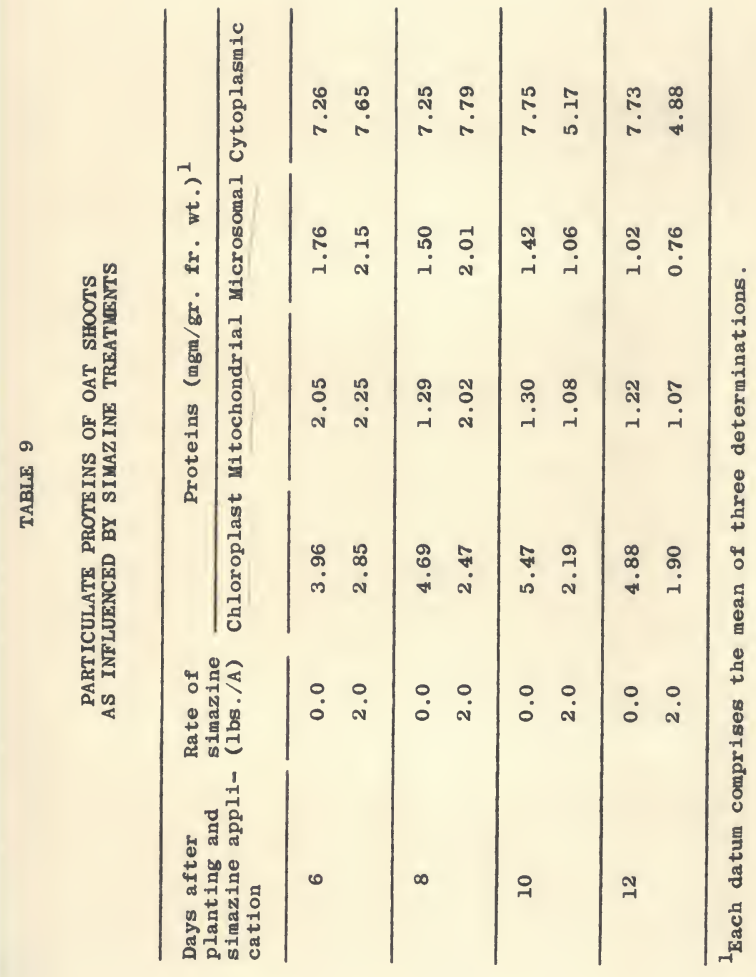


The simazine treatment decreased the concentrations of all the four proteins in the third and fourth samples collected 10 and 12 days after simazine application. In these samples too, chloroplast proteins were affected more than others. The maximum decrease of 61 per cent occurred in the chloroplast proteins in the last sample.

The data were analyzed statistically and the results are shown in Table 10. The differences among proteins due to treatments and sampling intervals as well as various interactions were highly significant.

Incorporation of $\mathrm{c}^{14}$-Leucine in Protein

The results of $\mathrm{C}^{14}$-leucine incorporation in the total and chloroplast proteins of plants from 0 and 2.0 1bs. simazine treatment are reported in Table 11. These incorporation studies were conducted to demonstrate the effect of simazine on the incorporation rate of $c^{14}$-leucine in protein.

In the first sample which was incubated six days after simazine application, incorporation of $c^{14}$-leucine in the total protein of tissues from the $2.0 \mathrm{lbs}$. simazine treatment was slightly enchanced. On the other hand, in the sample collected 10 days after simazine treatment, the rate of incorporation of radioactive leucine in the total protein of tissues grown in 2.0 lbs. treatment was reduced by three-fourths.

The results of this experiment show clearly that 
TABLE 10

ANALYSIS OF VARIANCE OF CONTENTS OF PARTICULATE PROTEINS OF OATS

\begin{tabular}{lcc}
\hline Sources of variation & D.F. & \multicolumn{1}{c}{ Variance } \\
\cline { 2 - 3 } & & $\begin{array}{c}\text { Protein } \\
\text { (mgm/gr. fr. wt.) }\end{array}$ \\
\cline { 2 - 3 } Treatments & 1 & $8.00^{* *}$ \\
Intervals & 3 & $6.94^{* *}$ \\
Proteins & 3 & $151.23^{* *}$ \\
Tr. X Intervals & 3 & $4.76^{* *}$ \\
Tr. X Proteins & 3 & $7.68^{* *}$ \\
Intervals X Proteins & 9 & $0.75^{* *}$ \\
Tr. X Intervals X Proteins & 9 & $1.27^{* *}$ \\
Error & 64 & $0.03^{*}$ \\
\hline * P <.05 & & \\
** P L.01 & & \\
\hline
\end{tabular}


TABLE 11

\section{RATE OF INCORPORATION OF $C^{14}$-LEUCINE IN TOTAL AND CHLOROPLAST PROTEINS OF CHECK AND SIMAZINE TREATED OAT SHOOTS ${ }^{1}$}

\begin{tabular}{|c|c|c|c|}
\hline \multirow{2}{*}{$\begin{array}{l}\text { Days after } \\
\text { planting and } \\
\text { simazine appli- } \\
\text { cation }\end{array}$} & \multirow{2}{*}{$\begin{array}{l}\text { Rate of } \\
\text { simazine } \\
(1 \mathrm{bs} . / \mathrm{A})\end{array}$} & \multicolumn{2}{|c|}{ Cpm./gr. fr. wt. ${ }^{2}$} \\
\hline & & Total protein & Chloroplast protein \\
\hline \multirow[t]{2}{*}{6} & 0.0 & 6,901 & 2,515 \\
\hline & 2.0 & 7,003 & 1,062 \\
\hline \multirow[t]{2}{*}{10} & 0.0 & 14,313 & 3,195 \\
\hline & 2.0 & 3,695 & 840 \\
\hline
\end{tabular}

$I_{\text {The }}$ fissue was incubated in $25 \mathrm{ml}$ which contained $5 \mu \mathrm{c}$ of $\mathrm{c}^{14}$-leucine for 1.5 hours.

2 Each datum comprises the mean of two determinations. 
the incorporation rate of leucine in the chloroplast protelns of plants grown in 2.0 lbs. simazine treatment was decreased to less than half in the first sample. In the sample collected 10 days after treatment, the incorporation rate for chloroplast protein reduced by three-fourths, approximately the same rate of reduction for total proteins.

Another experiment was conducted to demonstrate again the effect of simazine on $\mathrm{C}^{14}$-leucine incorporation in total and chloroplast proteins. In this experiment, instead of simazine application pre-emergence, plants were grown for 10 days without any previous treatment and the simazine at $1 \mathrm{p} . \mathrm{p} . \mathrm{m}$. concentration was added in the incubation mixture.

The results shown in Table 12 indicate that simazine decreased the incorporation rate of $\mathrm{C}^{14}$-leucine in total and chloroplast proteins. The differences in incorporation rates in this experiment were not as distinct as in the previous experiment in which simazine was applied at time of planting. The results of both experiments, however, suggest that simazine inhibited the incorporation of $\mathrm{C}^{14}$-leucine in protein.

Two other radioisotope experiments were conducted to determine if the incorporation rate of $\mathrm{C}^{14}$-leucine in protein is affected by inhibition in photosynthesis or if it is independent of photosynthetic inhibition. 
TABLE 12

RATE OF INCORPORATION OF $C^{14}$-LEUCINE IN TOTAL AND CHLOROPLAST PROTEINS OF 10-DAY OLD SHOOT TISSUE INCUBATED WITH AND WITHOUT SIMAZINE ${ }^{1}$

\begin{tabular}{ccc}
\hline $\begin{array}{l}\text { Treatments } \\
\text { (p.p.m. simazine) }\end{array}$ & Cpm./gr. fr. wt. ${ }^{2}$ \\
0.0 & 10,525 & \\
1.0 & 9,640 & 1,896 \\
& & 1,740 \\
\hline
\end{tabular}

$1_{\text {The }}$ tissue was incubated in $25 \mathrm{ml}$ which contained $3 \mu \mathrm{c}$ of $\mathrm{C}^{14}$-leucine for three hours.

${ }^{2}$ Each datum comprises the mean of two determinations. 
In the first experiment, 6 per cent glucose was supplied in the incubation mixture to the tissues grown in 0 and 2.0 lbs. simazine treatment. Table 13 shows that glucose inhibited $\mathrm{C}^{14}$-leucine incorporation in total and chloroplast proteins of tissues from 0 lbs. treatment. In contrast, glucose increased $\mathrm{C}^{14}$-leucine incorporation in total and chloroplast proteins of tissues grown in 2.0 lbs. simazine treatment. The incorporation rate was approximately doubled in the tissues from 2.0 lbs. treatment and supplied with glucose. The results of $\mathrm{C}^{14}$-leucine incorporation in proteins of tissues from 0 and 2.0 lbs. simazine treatment and grown in dark and light are shown in Table 14. The incorporation rate of $\mathrm{C}^{14}$-leucine in the protein of tissue subjected to 2.0 lbs. simazine treatment and grown in light was slightly higher than for etiolated tissues of $01 \mathrm{~b}$. treatment.

Incorporation of $\mathrm{p}^{32}$ in Ribosomal RNA

The RNA contents of different sizes of ribosomes in the plants from 0 and $2.0 \mathrm{lbs}$. simazine treatment are listed in Table 15 and illustrated in Figure 6. The monosome $(70 \mathrm{~S})_{1}$, disomes $(70 \mathrm{~S})_{2},(70 \mathrm{~S})_{3}$ and polysomes $7(70 \mathrm{~S})_{3}$ were found in the sixth, ninth, twelfth and pellet fractions of density gradient. In general, the concentrations of RNA in all the mentioned ribosomes were decreased by simazine treatment. These decreases were $33.8,36.5,36.4$ and 39.8 per cent, 
RATE OF INCORPORATION OF $\mathrm{C}^{14}$-LEUCINE IN TOTAL AND CHLOROPLAST PROTEINS OF CHECK AND SIMAZINE TREATED 10-DAY OLD OAT SHOOTS INCUBATED WITH AND WITHOUT GLUCOSE ${ }^{1}$

\begin{tabular}{|c|c|c|c|}
\hline \multirow{2}{*}{$\begin{array}{l}\text { Rate of simazine } \\
(1 \mathrm{bs} . / \mathrm{A})\end{array}$} & \multirow{2}{*}{$\begin{array}{l}\text { Per cent glucose } \\
\text { in incubation } \\
\text { mixture }\end{array}$} & \multicolumn{2}{|c|}{ Cpm./gr. fr. wt. ${ }^{2}$} \\
\hline & & $\begin{array}{l}\text { Total } \\
\text { protein }\end{array}$ & $\begin{array}{l}\text { Chloroplast } \\
\text { protein }\end{array}$ \\
\hline \multirow[t]{2}{*}{0.0} & 6 & 5,554 & 1,554 \\
\hline & 0 & 10,555 & 2,405 \\
\hline \multirow[t]{2}{*}{2.0} & 6 & 2,967 & 1,718 \\
\hline & 0 & 1,310 & 786 \\
\hline
\end{tabular}

$1_{\text {The }} t$ issue was incubated in $25 \mathrm{ml}$ which contained $1.5 \mu \mathrm{c}$ of $\mathrm{c}^{14}$-leucine for three hours.

2 Each datum comprises the mean of two determinations. 
TABLE 14

RATE OF INCORPORATION OF C $\mathrm{C}^{14}$-LEUCINE IN TOTAL PROTEIN OF CHECK AND SIMAZINE TREATED 10-DAY OLD OAT SHOOT TISSUE GROWN IN LIGHT AND DARK ${ }^{1}$

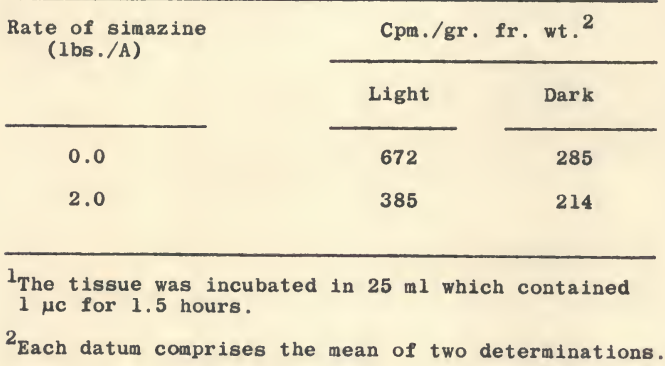




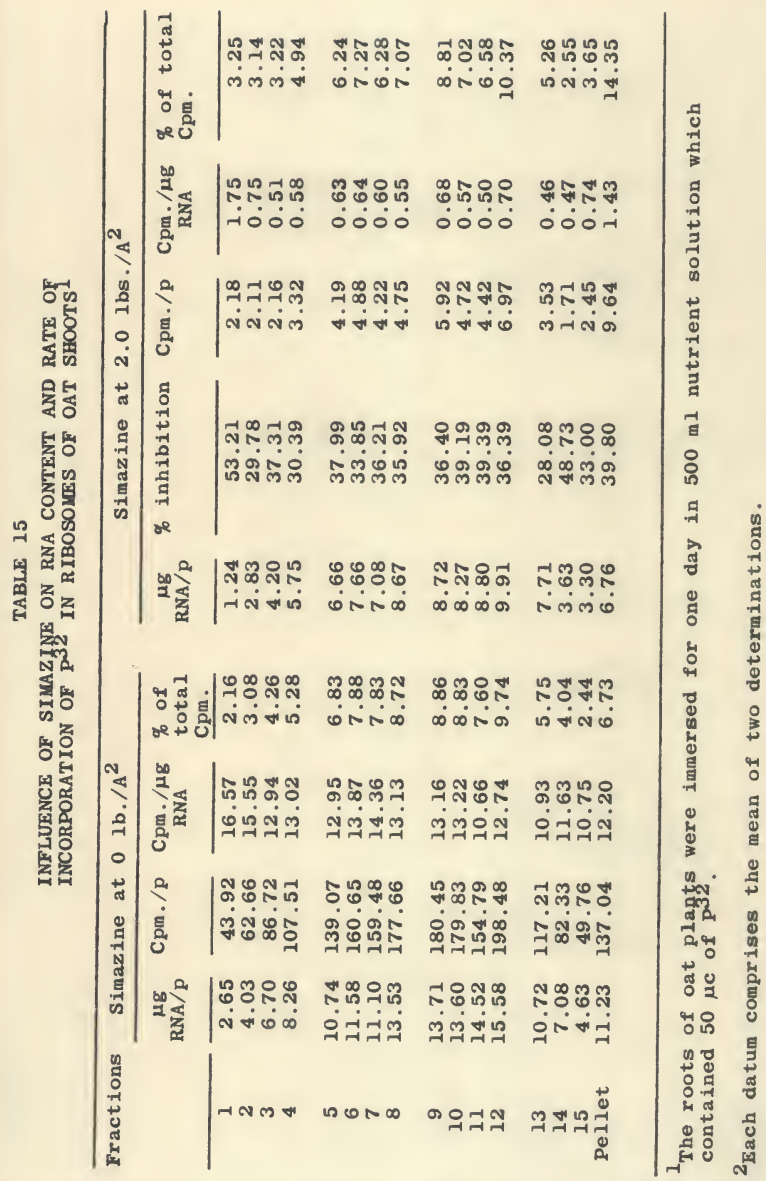


respectively in $(70 S)_{1},(70 S)_{2},(70 S)_{3}$ and $7(70 S)_{3}$ ribosomes.

The results of $\mathrm{p}^{32}$ incorporation in ribosomes are given in Table 15 and Figure 6 . The incorporation rate of $\mathrm{p}^{32}$ in the RNA of ribosomes was almost completely blocked in the tissues from 2.0 lbs. simazine treatment. Only 3.3 per cent incorporation was found in the ribosomal RNA of plants subjected to 2.0 lbs. of simazine per acre treatment.

The ratios of different ribosomes with (70s) ribosome in the tissues from 0 and $2.0 \mathrm{lbs}$. treatment are shown in Table 16 . These ratios decreased slightly in tissues grown in $2.0 \mathrm{lbs}$. of simazine treatment. A greater decrease was found in the ratio of polysomes with monosomes. 


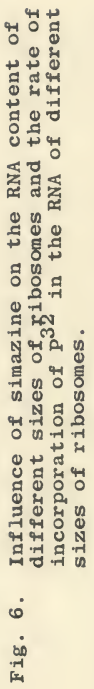




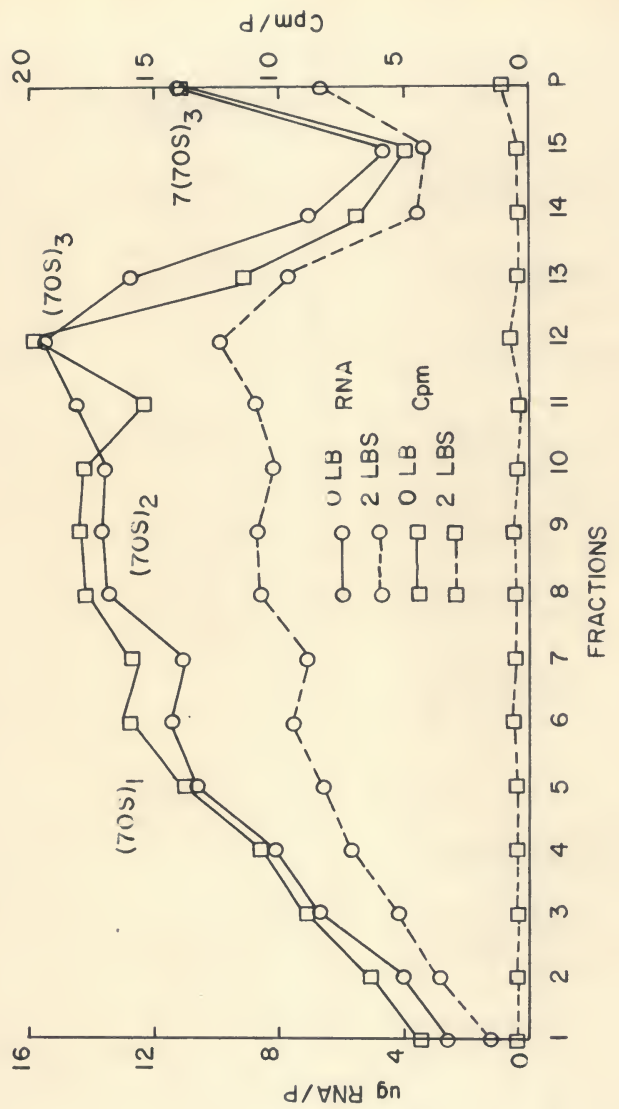


TABLE 16

A COMPARISON OF CHANGES IN THE RATIOS OF DIFFERENT RIBOSOMES IN OAT PLANTS TREATED WITH SIMAZINE

\begin{tabular}{lcc}
\hline Ribosomes & \multicolumn{2}{c}{ Ratios of ribosomes with monosome } \\
\cline { 2 - 3 } & 0 1b. simazine/A & 2.0 lbs. simazine/A \\
$(70 S)_{2} /(70 S)_{1}$ & 1.18 & 1.14 \\
$(70 S)_{3} /(70 S)_{1}$ & 1.35 & 1.29 \\
$7(70 S)_{3} /(70 S)_{1}$ & 0.97 & 0.88 \\
\hline
\end{tabular}




\section{DISCUSSION}

In the studies reported here, the symptoms of simazine toxicity appeared first in the form of yellowing of leaves. Necrosis later began in the leaf tips and soon spread throughout. Death of the plants occurred 14 days after the application of simazine.

Similar development of phytotoxicity symptoms as a result of simazine application has been reported by Schneider (93) in wheat and Coleus blumei. Also, Rodgers and Wilcox (89) reported leaf chlorosis in oat plants seven days old grown in Lakeland fine sandy soil. These plants died 14 days after planting.

The fresh and dry weights of tissues from 0.5 1b. simazine treatment slightly increased in the first samples collected six days after treatment. However, fresh and dry weights of oat shoots decreased in later samples from this treatment. The fresh and dry weights of oat shoots from 2.0 lbs. simazine treatment were decreased in all samples. The maximum reduction in fresh and dry weights occurred in the last sample, collected 12 days after simazine treatment.

Burnside and Behrens (19) reported that the dry weight of oat plants was slightly increased by low concentrations of simazine and decreased by higher 
concentrations. The results reported herein for higher concentrations of simazine are in agreement with these findings as well as with those of Moreland (71) and Sheets (95).

Photosynthesis is the process of green plants by which food reserves are synthesized. The net gain in fresh and dry weights depends on this fundamental process. Several workers $(8,34,35,42,71,91)$ have reported that triazines inhibit photosynthesis. Therefore, a determination of the relationship between this inhibition and the reduced fresh and dry weights of simazine treated tissues was logical. Other metabolic processes, however, may be inhibited by simazine and consequently influence fresh and dry weights.

A marked influence of simazine was observed on the chlorophyll contents of oat plants. In general, a reduction in total chlorophyll content of oat plants occurred. The maximum decrease of 67 per cent was found in the sample analyzed 12 days after simazine application. The analysis of chlorophyl1 a and chlorophyl1 b, which are the two major chlorophylls involved in photosynthesis, indicated that the concentration of both was decreased by this herbicide. In earlier samples, chlorophyll a was reduced more than chlorophyll b, but this finding was reversed in later samples.

The observations of Schneider (93) demonstrate qualitative changes in the chlorophyll contents of 
simazine treated plants. Recently, Ashton and Bisalputra (4) reported that atrazine caused a decrease in the amount of chlorophyll present in Chlore1la. No published data are available regarding the quantitative changes in chlorophylls as the result of simazine application.

Since protein is an important component of chloroplasts, a study of changes in protein contents of oats was appropriate. In general, simazine inhibited protein synthesis. Protein per gram fresh and dry tissue of plants from 0.5 lb. simazine treatment decreased in all samples. However, the protein content per plant from this treatment slightly increased by the sixth day after treatment. In other samples, protein per plant was reduced. Protein per gram fresh tissue in the plants subjected to 2.0 lbs. simazine treatment increased in the first and second samples but decreased in samples collected 10 and 12 days after treatment. The per plant protein in the plants from 2.0 lbs. simazine treatment slightly increased in the first sample, but decreased in the later three samples. Protein per gram dry tissue in the plants from 2.0 lbs. simazine treatment was decreased in all samples.

In plants from the 2.0 1bs. simazine treatment, the concentration of protein per plant was not decreased in the first two samples. On the other hand, fresh weight of plants in this treatment was reduced. This 
reduction probably accounts for the increase in the concentrations of protein per gram fresh tissue. The reduction in fresh and dry weights may be due to inhibited photosynthesis and speedy depletion of reserve carbohydrates in the intermediary metabolism. No experimental results are available to elucidate the effects of triazines on the protein metabolism of plants. Several investigators $(10,40$, $82,94,119)$ have mentioned that 2,4-D increased the protein content of shoots of different plants. The results of this investigation are contradictory to the results reported for 2,4-D. The mode of action of triazines and 2,4-D herbicides apparently is different. The reason for this difference will be discussed later.

The results of the analysis of particulate proteins show that the chloroplast proteins are affected severely by simazine treatment. Reduction in the concentration of chloroplast proteins began at the initiation of the experiment. On the other hand, the concentrations of mitochondrial, microsomal and cytoplasmic proteins increased in the first two samples. In the third and fourth samples, these proteins also were decreased. The maximum decrease was 61 per cent in the chloroplast proteins in the sample analyzed 12 days after treatment. Thus, this experiment demonstrated that simazine affects chloroplast proteins and subsequently the other proteins. Ashton et al. $(5,6)$, in their histological studies of bean shoots, observed alteration of chloroplast 
structure by atrazine treatment. In the late stages of phytotoxicity, they found disintegration of chloroplast structure. The major components of chloroplasts are protein and lipids. The finding in the present investigation that simazine primarily affects chloroplast protein may be one reason for the destruction and disintegration of chloroplasts.

The results of the $\mathrm{Cl}^{14}$-leucine incorporation experiments provide further evidence for the influence of simazine on protein metabolism. The incorporation rate of $\mathrm{C}^{14}$-leucine was slightly enhanced in the total protein content of tissue from plants six days old from 0 and $2.0 \mathrm{lbs}$. treatment. In the same experiment, great inhibition in the incorporation rate was found in the chloroplast proteins. The incorporation rate of radioactive leucine in total protein was decreased in tissues from plants 10 days old from the 2.0 lbs. treatment. In

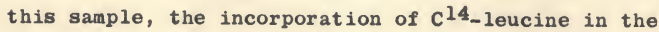
chloroplast proteins decreased to a greater extent than in the first sample. These results further support the previous findings that simazine inhibits protein synthesis and this inhibition is more pronounced in the chloroplast proteins.

Instead of adding simazine pre-emergence, it was added in the incubation mixture for the oat shoots 10 days old and the $\mathrm{C}^{14}$-leucine incorporation in total and chloroplast proteins was determined. The results 
of this experiment were similar to the previous radioisotope experiment. However, the differences in the incorporation rates of plants from 0 and $2.0 \mathrm{lbs}$. treatment were not distinct. The low solubility of simazine may be the reason for this discrepancy in results. Davis et al. (28) and Schneider (93) reported that simazine and other triazines are readily absorbed by the roots. Several workers $(28,38,39)$ demonstrated negligible foliar absorption of simazine.

The primary mode of action of triazines has been reported by various investigators as the inhibition of photosynthesis $(42,71,91$ 130). However, Ashton and Uribe (7) concluded from their experiments that atrazine not only blocks photosynthesis but also interferes with other metabolic processes independent of photosynthesis. Based upon the results of these several workers, two experiments were planned to determine if inhibition in protein synthesis is affected by inhibition in photosynthesis, or if it is independent of the photosynthetic block.

Glucose was supplied in the incubation mixture for tissues from 0 and $2.0 \mathrm{lbs}$. simazine rates and the total and chloroplast proteins were analyzed for $\mathrm{c}^{14}$ leucine incorporation. The incorporation rate of $\mathrm{C}^{14}$ leucine in the total and chloroplast proteins of simazine treated tissue was improved by the addition of glucose in incubation mixture, but the incorporation rate was not normal as in 0 rate. 
These results suggest that photosynthetic inhibition affects protein synthesis. Since the incorporation rate was not normal in the treatments including glucose, simazine probably may also affect protein synthesis directly.

In another experiment, photosynthesis was blocked by simazine and dark treatments and the incorporation of $\mathrm{c}^{14}$-leucine in total protein of these tissues was determined. The inhibition in leucine incorporation was slightly greater due to dark than simazine treatment. These results further support the findings that the inhibition of protein synthesis is caused by abnormalities in photosynthesis in plant response to simazine.

The free amino acid content decreased simultaneously with an increase in the concentration of protein in plants from the $2.01 \mathrm{bs}$. simazine treatment six and eight days after treatment. In the third and fourth samples analyzed 10 and 12 days after treatment, the concentration of free amino acids increased and the protein content decreased.

These findings indicate that simazine does not inhibit the synthesis of free amino acids. The decrease and subsequent increase in amino acids concentration probably were due to the utilization of free amino acids in protein synthesis. Zweig and Ashton (130) concluded from their experiments that aspartic and glutamic acids 
are not affected by atrazine phytotoxicity. Other amino acids may be synthesized from these amino acids by transamination mechanism.

The results of this investigation indicate that RNA synthesis is affected by simazine treatment in the same way as protein synthesis. The RNA per gram Iresh and dry tissue in plants from $0.5 \mathrm{lb}$. treatment decreased in all four samples. The RNA content per gram of fresh $t$ issue in plants from 2.0 lbs. simazine treatment increased in the first two samples and decreased in later samples. In the first and second samples, the differences between the RNA content per gram dry tissue in plants from 0 and 2.0 lbs. simazine treatment were not distinct. In the later samples, the RNA content per gram dry tissue decreased in plants from 2.0 lbs. simazine treatment. No noticeable differences were observed in per plant RNA content in different treatments in the first sample, but it decreased in the other three samples.

The increase in RNA content in the tissues from 2.0 1bs. simazine treatment collected six and eight days after treatment may be due to the fact that there was no change in the net concentration of RNA in this treatment, whereas the fresh weight was decreased. The pattern of changes in RNA concentration was similar to changes in protein contents. This relationship indicates that changes in protein contents are due to the changes in RNA concentrations. 
Several investigators $(10,62,86,119)$

reported that 2,4-D increased the concentrations of RNA of plant shoots. The results of the reported investigation are not in the line of the results reported for 2, 4-D.

The results of the study of ribosomal RNA indicate that simazine influenced RNA contents of all sizes of ribosomes. The reduction in the RNA content of ribosomes was in the order of polysome, $(70 \mathrm{~S})_{2}$ and $(70)_{3}$. There were slight differences in the ratios of different sizes of ribosomes with monosomes. The ratio was more reduced in polysomes followed by $(70 \mathrm{~S})_{3}$ and $(70)_{2}$. The rate of incorporation of $\mathrm{p}^{32}$ in the ribosomal RNA was almost completely stopped in tissues from 2.0 1bs. simazine treatment. The results of $\mathrm{p}^{32}$ incorporation study suggest that the synthesis of ribosomal RNA is completely inhibited by simazine treatment. The differences in the influence of 2,4-D and simazine herbicides on protein and RNA metabolism indicate that the mode of action of these herbicides are different. van Overbeek (81) commented,"2,4-D causes abnormal growth whereas simazine upsets photosynthesis". He further added, "this extra growth induced by 2,4-D herbicide is caused by a production of extra RNA". The production of extra RNA synthesizes extra protein. 


\section{SUMMARY AND CONCLUSIONS}

Seminole varlety of oats were grown under controlled temperature, photoperiod and light intensity in sand with the use of Hoagland-Arnon nutrient solution. Simazine was added to sand as pre-emergence treatment. Samples of oat shoots were collected at two-day intervals beginning six days and terminating 12 days after treatment. Growth studies included the observation of phytotoxicity symptoms and the determination of fresh and dry weights. Determinations were made of total protein, particulate proteins, total RNA, ribosomal RNA, chlorophylls and free amino acids. The influence of simazine on protein synthesis was studied by the use of C $^{14}$-leucine incorporation and on ribosomal RNA synthesis by the use of $\mathrm{p}^{32}$.

The phytotoxic symptoms of simazine appeared in the form of yellowing of leaves by the sixth day after treatment. Necrosis later began in the leaf tips and rapldiy spread throughout. Plants died in most cases 14 days after the application of simazine.

slight increases occurred in the fresh weight of plants from $0.5 \mathrm{lb}$. simazine treatment in the first sample, but fresh and dry weights of plants from 0.5 
and $2.0 \mathrm{lbs}$. simazine treatment were decreased in the samples collected 8,10 and 12 days after treatment.

Simazine reduced the concentrations of chlorophyll a and chlorophyll $\underline{b}$ in all four samples. In the earlier two samples, chlorophyll a content was reduced more than chlorophyll b, but this finding was reversed 12 days after treatment.

Total protein content was reduced in oat plants from the $0.5 \mathrm{lb}$. simazine treatment in all four samples. The 2.0 lbs. rate of simazine caused an increase in total protein content per gram fresh tissue in plants analyzed six and eight days after treatment. In later samples, the protein content in this treatment decreased. The influence of simazine on total RNA was similar to that on protein. RNA content of plants from 0.5 lb. simazine treatment was decreased in all samples. The concentration of RNA per gram fresh tissue in plants from the 2.0 lbs. treatment increased in the first and second samples and decreased in others. However, RNA per plant in this treatment slightly increased in the first sample and decreased in other three samples. Dry weight determinations of RNA showed no differences in the first and second samples of plants from the 0 and 2.0 Ibs. treatment, but a reduction occurred in the third and fourth samples of plants from the $2.0 \mathrm{lbs}$. treatment.

Simazine caused a decrease in the concentrations of free amino acids in the first two samples and an 
increase in the later samples.

Chloroplast proteins were reduced in plants from the $2.0 \mathrm{lbs}$. simazine treatment in all samples. However, the concentrations of mitochondrial, microsomal and cytoplasmic proteins in this treatment increased in the first two samples but decreased in samples collected 10 and 12 days after treatment.

Simazine caused a slight increase in the rate of incorporation of leucine in total protein of tissues collected six days after treatment. The rate of $\mathrm{C}^{14}$-leucine incorporation in total protein decreased in tissues collected 10 days after the application of simazine. Whereas the rate of $\mathrm{c}^{14}$-leucine incorporation in chloroplast proteins of plants from the $2.01 \mathrm{bs}$. treatment decreased in both samples.

Addition of 6 per cent glucose to $\mathrm{C}^{14}$-leucine improved the incorporation rate of radioactive leucine in total and chloroplast proteins of plants from $2.0 \mathrm{lbs}$. simazine treatment. The incorporation rate of $\mathrm{C}^{14}$ leucine in total protein of plants from 2.0 lbs. simazine treatment was slightly higher in comparison to the incorporation rate of etiolated tissues from $0 \mathrm{lb}$.

The analyses of RNA of different sizes of ribosomes indicated that simazine affected all sizes of ribosomes. The incorporation of $\mathrm{p}^{32}$ in ribosomal RNA was almost completely blocked in the plants from $2.01 \mathrm{bs}$. simazine treatment. 
Based on results of this investigation, the

following conclusions appear justifled concerning the influence of simazine applied pre-emergence to oats:

1. The phytotoxic symptoms of simazine appear six days after treatment in the form of yellowing of leaves followed by necrosis of leaf tips. The plants die 14 days after treatment.

2. Simazine causes decrease in fresh and dry weights of shoots.

3. The concentrations of chlorophyll a and chlorophyll b are decreased by simazine treatmeñt.

4. Simazine decreases concentrations of free amino acids in plants six and eight days after treatment, but these concentrations are increased by the tenth day.

5. Simazine causes a decrease in total protein per plant eight days after the application of simazine.

6. Reduction in the concentration of chloroplast proteins begins as early as six days after simazine treatment. The concentrations of mitochondrial, microsomal and cytoplasmic proteins increase in plants through the eighth day after treatment and then decreases.

7. Simazine inhibits incorporation of $\mathrm{c}^{14}$-leucfye in chloroplast proteins. The incorporation rate of $\mathrm{C}^{14}$ leucine in total protein increases slightly six days after treatment but decreases after another four days.

8. Glucose improves the rate of incorporation of radioactive leucine in total and chloroplast proteins of plants from simazine treatment.

9. Simazine causes a decrease in total RNA per plant eight days after simazine treatment.

10. Simazine causes reduction in RNA contents in all sizes of ribosomes.

11. The rate of incorporation of $\mathrm{p}^{32}$ in ribosomal RNA is almost completely blocked due to simazine treatment. 


\section{BIBLIOGRAPHY}

1. Akers, T. J. and S. C. Fang. 1956. Studies on plant metabolism. VI. Effect of 2,4-D on the metabolism of aspartic acid and glutamic acid in the bean plant. Plant Physiol. 31:34-37.

2. Allen, W. S. and R. D. Palmer. 1963. The mode of action of simazine in barley. Weeds $11: 27-30$.

3. Ashton, F. M. 1962. Action spectra of atrazine injury. plant Physiol (suppl.) 35:XXV.

4. and T. Bisalputra. 1964. Effect of atrazine on Chlorella. Plant Physiol. (suppl.) $39: \operatorname{XXXII.~}$

5. E. M. Gifford, Jr. and T. Bisalputra. 1963. Structural changes in Phaseolus vulgaris induced by atrazine. I. Histological changes. Bot. Gaz. $124: 329-335$.

6.

structuraI' changes in phaseolus vulgar is induced by atrazine. II. Effects on ine structure of chloroplasts. Bot. Gaz, 125:336-343.

7 . and E. G. Uribe. 1962. Effect of atrazine on sucrose-C ${ }^{14}$ and serine-C ${ }^{14}$ metabolism. Weeds $10: 295-297$.

8. , G. Zweig and G. W. Mason. 1960. The effect of certain triazines on $\mathrm{C}^{14} \mathrm{O}_{2}$ fixation in red kidney beans. Weeds $8: 448-451$.

9. Association of official Agricultural Chemists. 1955. Washington, D.C. $123 \mathrm{p}$.

10. Basler, E. and K. Nakazawa. 1960. Some effects of 2,4-dichlorophenoxyacetic acid on nucleic acids of cotton cotyledon tissue. plant Physiol. (suppl.) 35 : XXVIII.

11. Benson, A. F., J. F. G. M. Wintermans and R. Wiser. 1959. Chloroplast lipids as carbohydrate reservoirs. Plant Physiol. 34:315-317. 
12. Bernlohr, R. W. and G. C. Webster. 1958. Transfer of oxygen-18 during amino acid activation. Arch. Biochem. Biophys. 73:276-278.

13. Bishop, J., E. Allen, J. Leahy, A. Morris and R. Schweet. 1960. Stages in hemoglobin synthesis in a cell-free system. Federation Proc. 19:346.

14. Biswas, P. K. 1964, Absorption, diffusion and translocation of $\mathrm{C}^{14}$-labeled herbicides by peanut leaves. Weeds 12:31-32.

15. Brawermann, G. and E. Charagaff. 1959. Changes in protein and ribonucleic acid during the formation of chloroplast in Euglena gracillis. Biochim. et Biophys. Acta $31: 164-171$.

16. British Weed Control Counc1l. 1960. Weed Control Handbook, (Ed. E. K. Woodford). Blackwell Scientific Publications, Oxford (England). $264 \mathrm{p}$.

17. Brown, G. L. and G. Zubay. 1960. Physical properties of soluble RNA of Escherichia coli. J. Mol. Biol. 2:287-296.

18. Buchholtz, F. P. 1963. Use of atrazine and other triazine herbicides in control of quackgrass in corn fields. Weeds 11:202-207.

19. Burnside, O. C. and R. Behrens. 1961. Phytotoxicity of simazine. Weeds $9: 154-157$.

20. Butler, J. A. V., P. Cohn and P. Simson. 1960. The presence of basic proteins in microsomes. Biochim. et Biophys. Acta 38:386-388.

21. Castelfranco, P. and M. Brown. 1962. Purification and properties of the simazine-resistant factor of Zea mays. Weeds 10:131-135.

22. C. L. Foy and D. B. Deutsch. 1961. Non-enzymatic detoxification of 2-chloro-4,6-bis (ethylamino)-s-triazine (simazine) by extracts of Zea mays. Weēds 9:580-591.

23. Chrispeels, M. J. and J. B. Hanson. 1962. The increase in ribonucleic acid content of cytoplasmic particulates of soybean hypocotyl induced by 2,4dichlorophenoxyacetic acid. Weeds 10:123-125.

24. Cole, R. D., J. Coote and T. S. Work. 1957. Act1vation of amino acids by soluble enzymes from pancreas and other tissues. Nature 179:199. 
25. Crafts, A. S. 1960. The Chemistry and Mode of Action of Herbicides. Interscience Publishers, Inc., New York. 104-125 p.

26. Crick, F. H. C. 1958. On protein synthesis. Symp. Soc. Expt1. Biol. XII:138-163.

27. Crombie, W. M. 1958. Fatty acids in chloroplasts and leaves. J. Expt1. Bot. 9:254-261.

28. Davis, D. E., H. H. Funderburk, Jr. and N. G Sansing. 1959. The absorption and translocation of ci4-labeled simazine by corn, cotton and cucumber. Weeds 7:300-309.

29. Davis, J. W. and G. D. Novelli. 1958. The activation of amino acids in extracts of pea seedlings. Arch. Biochem. Biophys. 75:299-308.

30. DeMoss, J. A. and G. D. Novelli. 1956. An amino acid dependent exchange between $\mathrm{p}^{32}$ labeled inorganic pyrophosphate and ATP in microbial extracts. Biochim. et Biophys. Acta $22: 49-61$.

31. , S. M. Genuth and G. D. Novelli. 1956. The enzymatic activation of amino acids via their acyladenylate derivatives. Proc. Natl. Acad. Sci. U. S. $42: 325-332$.

32. Dunham, R. S. 1951. General responses in crop plants. In Plant Growth Substances, (Ed. F. Skoog). 195-206 p.

33. Eastin, E. F., R. D. Palmer and C. O. Grogan. 1964. Mode of action of atrazine and simazine in susceptible and resistant lines of corn. Weeds 12:49-52.

34. Exer, B. 1958. Über Pflanzenwachstumsregulatoren. Der Einfluss von simazin auf den Pflanzenst of fwechsel. Experientia $14: 135$.

35.

1961. Hemung der hillrektion durch herbizide. Weed Res. 1:233-244.

36. Fink, R. J. and O. H. Fletchall. 1963. Forage establishment in soil containing atrazine or simazine residues. Weeds 11:81-83.

37. Foy, C. L. 1962. Accumulation of s-triazine derivatives in the lysigenous glands of Gossypiūm hirsutum L. Plant Physiol. (suppl.) $37: X X V$.

38. 1964. Volatility and tracer studies with alkylamino-s-triazines. Weeds $12: 103-108$. and P. Castelfranco. 1961. Distribution and metabolic fate of $\mathrm{C}^{14}$-labeled 2-chloro-4,6-bis (ethylamino)-s-triazines in relation to phytotoxicity. Plant Physiol. (suppl.) 35:XXVIII. 
40. Freiberg, S. R. and H. E. Clark. 1955. Changes in nitrogen fractions and proteolytic enzymes of soybean plant treated with 2,4-dichlorophenoxy-acetic acid. Plant Physiol. 30:39-46.

41. Frey-Wyssling, A. 1953. The submicroscopic Morphology of Protoplasm and its Derivatives. Elsevier Publishing Co., Amsterdam (Holland), 243-262 p.

42. Funderburk, H. H. Jr. and D. E. Davis. 1963. Metabolism of $\mathrm{C}^{14}$-chain and ring labeled simazine by several other plants. Proc. SwC. 16:387.

43.

and 1963. The metabolism of CI4-chain and ring labeled simazine by corn and the effect of atrazine on plant respiratory enzymes. Weeds 11:101-104.

44. Fults, J. L. and M. G. Payne. 1956. Effect of 2,4-dichlorophenoxyacetic acid and maleic hydrazide on free amino acids and proteins in potato, sugar beet and bean tops. Bot. Gaz. 118:130-133.

45. Gast, A. 1958. Über Pflanzenwachstumsregulatoren. Beitrage zur Kenntris der Phytotosischen Wirkung von Triazinen. Experientia 14:134.

46. Gierer, A. 1963. Function of aggregated reticulocyte ribosomes in protein synthesis. J. Mol. Biol. 6:148-157.

47. Gigger, R. P. and J. H. Flangan. 1960. A report on atrazine post-emergence in corn, weed control and corn plant residue analysis. Proc. NEWCC. 14:231-236.

48. Good, N. E. 1961. Inhibitors of Hill reaction. Plant Physiol. 36:788-803.

49. Gross1, L. G. and K. Maldave. 1959. Transfer of RNA-bound amino acids to microsomal proteins. Biochim. et Biophys, acta 35:275-277.

50. Grover, R. 1962 Uptake and distribution of simazine-C 14 and propazine-C 14 in some tree seedlings. Plant Physiol. (suppl.) $37: X I I$.

51. Gysin, H. and E. Knüsli. 1960. Chemistry and herbicidal properties of triazine derivatives. Advances in Pest Control Res. $3: 289-358$.

52. Hamilton, R. H. 1964. A corn mutant deficient in 2,4-dihydroxy-7-methoxy-1,4-benzoxazin-3-one with an altered tolerance of atrazine. Weeds $12: 27-30$. 
53. , R. S. Bandurski and W. H. Reisch. 1962. Isolation and characterization of a cyclic hydroxamate from Zea mays. Cereal Chem. 39:107-113.

54.

55. Hill, R. and C. P. Whittingham. 1955. Photosynthesis. Methren and Co., Ltd., London (England). 164 p.

56. Hoagland, D. R. and D. I. Arnon. 1950. The water culture method for growing plants without soil. Calif. Agric. Expt. Sta. Cir. 347.

57. Hogland, M. B. 1955. An enzymatic mechanism for amino acid activation in animal tissues. Biochim. et Biophys. Acta $16: 288-289$.

58. , M. L. Stephenson, J. F. Scott, L. I. Hencht and P. C. Zamecnik. 1958. A soluble ribonucleic acid intermediate in protein synthesis. J. Biol. Chem. 231:241-257.

59. P. C. Zamecnik, N. Sharon, F. Lipman, II. P. Stulberg and P. D. Boyer. 1957. Oxygen transfer to AMP in the enzymatic synthesis of the hydroxamate of tryptophan. Biochim. et Biophys. Acta $26: 215-217$.

60. Jacob, F. and J. Monod. 1961. Genetic regulatory mechanisms in the synthesis of protein. J. Mol. Biol. 3:318-356.

61. Key, J. L. 1963. Studies on 2, 4-D induced changes in ribonucleic acid metabolism in excised corn mesocotyl tissue. Weeds $11: 177-180$.

62. and J. B. Hanson. 1961. Some effects of 2,4-dichlorophenoxyacetic acid on soluble nucleotides and nucleic acid of soybean seedlings. Plant physiol. $36: 145-152$.

63. Krinsky, N. I. and T. H. Goldsmith. 1960. The carotenoids of the flagellated alga, Euglena gracilis. Arch. Biochem. Biophys. 91:271-279.

64. Krishnaswamy, P. R. and A. Meister. 1960. Enzymatic synthesis and reaction of amino acyl adenylates. J. Biol. Chem. 235:408-415.

65. Lipman, F. 1958. Some facts and problems. Proc. Nat1. Acad. Sci. U.S. 44: 67-72. 
66. Lowry, O. H. , N. J. Rosenbrough, A. L. Farr and R. J. Randal1. 1951. Protein measurement with the Folin-Phenol reagent. J. Biol. Chem. 193:265-275.

67. Menke, W. 1963. Experiments made to elucidate the molecular structure of chloroplast. In Photosynthetic Mechanism of Green Plants. - Symp. Nat1. Acad. Sc1. U.S. 537-544 p.

68. McQuillen, K., R. B. Roberts and R. J. Britten. 1959. Synthesis of nascent protein by ribosomes in Escherichia coli. Proc. Nat1. Acad. Sci. U.S. $45: 1437-1449$.

69. Moldave, K. and C. G. Grossi. 1960. Studies on the nucleotide requirement in the transfer of amino acids from soluble RNA to microsomal proteins. Federation Proc. 19:351.

70. Montgomery, M. and V. H. Freed. 1961. The uptake, translocation and metabolism of simazine and atrazine by corn plants. Weeds $9: 231-237$.

71. Moreland, D. E. 1959. Studies on the mechanism of herbicidal action of 2-chloro-4,6-bis (ethylamino)s-triazine. Plant Physiol. 34:432-435.

72. and K. L. Hill. 1962. Interference of herbicide with the Hill reaction of isolated chloroplast. Weeds 10:229-235.

73. Nathans, D. and W. C. Hilsman. 1960. Purification of a supernatant factor required for transfer of sRNAamino acid to liver microsomes. Federation Proc. $19: 347$.

74. Niremberg, M. W. and J. H. Mathae1. 1961. Characteristics and stabilization of DNAase-sensitive protein synthesis in E.coli extracts. Proc. Natl. Acad. Sci. U.S. $47: 1580-$ I587.

75.

and 1961. The dependence of cell free protein synthes is in E.coli upon naturally occurring synthetic polyribonucleotides. Proc. Natl. Acad. Sci. U.S. $47: 1588-1601$.

76. Nishman, B. 1959. Incorporation and activation of amino acids by disrupted protoplasts of Escherichia coli. Biochim. et Biophys. Acta 32:18-31.

77. F. Bergmann and P. Berg. 1957. Observations on amino acid-dependent exchanges of inorganic pyrophosphate and ATP. Blochim. et Biophys. Acta $26: 639-640$. 
78. Novelli, G. D. 1958. Some problems concerning the activation of amino acids. Proc. Natl. Acad. Sci. U.S. $44: 816-892$.

79. Ogur, M. and G. Rosen. 1950. The nucleic actds of plant tissue. I. The extraction and estimation of deoxypentose nucleic and pentose nucleic acid. Arch. Biochem. Biophys. 25:262-276.

80. Okamoto, T. and M. Takanami. 1963. Interactions of ribosomal natural polynucleotides. Biochim. et Biophys. Acta 76:266-274.

81. Overbeek, van T. 1964. Survey of mechanism of herbicide action. In The Physiology and Biochemistry of Herbicides, (Ed. L. J. Audus). Academic Press, New York. 387-399 p.

82. Payne, M. G., J. L. Fults and R. J. Hay. 1952. The effect of $2,4-D$ treatment on free amino acids in potato tubers. Amer. Potato J. 29:142-150.

83. Peters, R. A. 1957. Notes on simazine as an herbicide on corn compared with several other materials. Proc. NEWCC. 11:283-285.

84. Plaisted, P. H. and D. P. Ryskiewich. 1962, The uptake and metabolism of $\mathrm{Cl}^{14}$-labeled simazine by young corn plants. Plant Physiol. (suppl.) $37: \mathrm{XXV}$.

85. Ragab, M. T.H. and J. P. McCollum. 1961. Degradation of C14-labeled simazine by plants and soil microorganism. Weeds 9:72-84.

86. Rebstock, T. L., C. L. Hamner and H. M. Se11. 1954. The influence of 2,4-dichlorophenoxyacetic acid on the phosphorus metabolism of cranberry bean plants (Phaseolus vulgaris). Plant Physiol. 29:490-491.

87. Risebrough, R. W., A. Tissieres and J. D. Watson. 1962. Messenger-RNA attachment to active ribosomes. Proc. Nat1. Acad. Sc1. U.S. 48:430-436.

88. Roberts, R. B., R. J. Britten and E. T. Bolton. 1958. Fractionation of Escherichia coli for kinetic studies. In Microsomal Particles and Protein Synthesis, (Ed. R. B. Roberts). Pergamon Press, New York. 84-94 p.

89. Rodgers, E. G. and M. Wilcox. 1963. Leaching characteristics of certain herbicides in selected soils. Fla. Agrl. Expt. Sta. Annu. Rept. 60 p. 
90. Roth, M. W. 1957. Etude comparee de la reaction du Mais et du Ble a la simazin, substance herbicide. Compt. Rend. Acad. Sc1. 10:942-944.

91. 1958. Plant growth regulators. The effect of simazine on the physlology of Elodea. Experientia 14:137-138.

92. Schirman, R. and K. P. Buchholtz, 1960. The effect of atrazine on the carbohydrate content levels in rhizomes of quackgrass. Proc. NCWCC. 17:19.

93. Schneider, E. O. 1959. A discussion of the mode of action, tolerance and soil type effects of the triazines. Proc. NEWCC. 13:416-420.

94. Se11, H. M., R. W. Luecke, B. M. Tayler and C. L. Hamner. 1949. Changes in chemical composition of the stems of red kidney bean plants treated with 2,4-dichlorophenoxyacetic acid. Plant Physiol. $24: 295-299$.

95. Sheets, T. J. 1961. Uptake and distribution of simazine by oat and cotton seedlings.. Weeds $9: 1-13$.

96. 1961. Toxicity, of simazine to seedling oat plants. Weeds $9: 331-333$.

97. Shigeura, H. T. and E. Chargaff. 1960. Action of ribonuclease on a microsomal ribonucleoprotein. Biochim. et Biophys. Acta 37:347-349.

98. Sissakin, N. M. 1958. Enzymology of the plastids. Adv. In Enzymol. 20:201-236.

99. Spencer, M., W. Fuller, M. H. F. Wilkins and G. L. Brown. 1962. Determination of helical configuration study of crystalline amino acid transfer ribonucleic acid. Nature 194:1014-1020.

100. Springer, F. B., Jr. 1960. The effectiveness of simazine in 1959. Proc. NEWCC. 14:237-240.

101. Smith, D. and K. P. Buchholtz. 1962, Transpiration rate reduced in plants with atrazine. Science $136: 263-264$.

102. Steel, R. G. D. and J. H. Torrie. 1960. Principles and Procedures of Statistics. McGraw-Hill Book Co., Inc., New York. 194-229 p.

103. Thomas, J. B., L. C. Post and N. Vetregt. 1954. Localization of chlorophyll within the chloroplast. Biochim. et Blophys. Acta 13:20-30. 
104. Tissieres, A. 1960. Some properties of soluble ribonucleic acid from Escherichia coli. J. Mol. Biol. 1:365-374.

105.

D. Schlessinger and F. Gros. 1960 . Amino acid incorporation into proteins by Escherichia coli ribosomes. Proc. Natl. Acad. Sci. U.S. 46:1450-1462.

106.

J. D. Watson and D. Schlessinger. 1959. Ribonucleoprotein particles from Escherichia coli. J. Mol. Biol. 1:221-233.

107. Trurnit, H. H. 1958. The architecture of the chloroplast in relation to its photosynthetic activities (Discussion). Brookhaven Symposia in Biol. 11:101-116.

108. T'SO, P., J. Bonner and H. Dintzis. 1958. On the similarity of amino acid composition of microsomal nucleoprotein particles. Arch. Biochem. Biophys. $76: 225-227$.

109. van Oorschot, J. L. P. and M. Belksma. 1961. A assembly for the continuous recording of $\mathrm{CO}_{2}$ exchange and transpiration of whole plants. Weed Res. 1:245-257.

110. Wahba, A. J., C. Basilo, J. F. Speyer, P. L. Lengyrel, R. S. Miller and S. Ochoa. 1962. Synthetic polynucleotides and the amino acid code. IV. Proc. Nat1. Acad. Sci. U.S. 48:1683-1686.

111. Wakonig, R. and T. J. Arnason. 1959. Chromosome breakage induced in Vicia faba root tips by $2,4,6-\operatorname{tr} i$ (ethylimino) $-1,3,5-$ triazine. Can. J. Bot. $37: 403$.

112. Warner, J. R., A. Rich and C. E. Ha11. 1962. Electron microscope studies of ribosomal clusters synthesizing hemoglobin. Science 138:1399-1403.

113. , P. K. Knopf and A. Rich. 1963. A multiple ribosomal structure in protein synthesis. Proc. Nat1. Acad. Sci. U.S. $49: 122-129$.

114. Webster, G. C. 1958. Activation of amino acids and amides by cell-free preparations. Arch. Biochem. Biophys. $82: 125-134$.

115. 1959. Protein synthesis by isolated nucleoprotein particles. Arch. Biochem. Biophys. $85: 159-170$.

116. 1960. Protein synthesis from amino acids associated with ribonucleic acid. Arch. Biochem. Biophys. 89:53-58. 
117 . .and J. B. Lingrel. 1961. Protein synthesis by isolated ribosomes. In The Biosynthesis of protein, (Ed. R. J. C. Harris). Academic Press, New York. 301-318 p.

118. Weller, L. E., C. D. Ball and H. M. Sell. 1957. Studies of maleic hydrazide interactions with thiol compounds. plant physiol. 32:140-147.

119. West, S. H., J. B. Hanson and J. L. Key. 1960. Effect of 2,4-dichloro-phenoxyacetic acid and protein content of seeding tissue. Weeds $8: 333-340$.

120. and J. B. Hanson. 1960. The degradation of isolated microsomes from cucumber and corn seedlings. Feeds 8:341-348.

121. Wills, G. D., D. E. Davis and H. H. Funderburk, Jr. 1963. The effect of atrazine on transpiration in corn, cotton and soybean. Weeds 11:253-255.

122. Wolf, F. T., J. G. Coniglio and J. T. Davis. 1962. Fatty acids of spinach chloroplasts. Plant Physiol. 37:83-85.

123. Wolken, J. J. 1956. A molecular morphology of Euglena gracilis var. bacillaris. J. Protozool. 3:211-221.

124. 1959. The structure of the chloroplast. Ann. Rev. Plant Physiol. 10-71-86.

125. 1961. Euglena: An Experimental Organism For Biochemical Studies. Rutgers Uni. Press, New Brunswick, New Jersey. 111-125 p.

126. 1963. The chloroplast structure in photosynthesis. In Photosynthetic Mechanism of Green Plants. Symp. Nat1. Acad. Sci. U.S. 575-587 p.

127. and F. A. Schwertz. 1953. Chlorophyll monolayers in chloroplasts. J. Gen. Physiol. 37:111-119.

128. Yoshida, A. and T. Tobita. 1960. Studies on the mechanism of protein synthesis. Non uniform incorporation of cl4-leucine into $\alpha$-amylase and the presence of $\alpha$-amylase precursor. Biochim. et Biophys. Acta 37:513-520.

129. Zamecnik, P. C. 1962. Unsettled question in the fleld of protein synthesis. Biochem. J. 85:257-264.

130. Zweig, G. and F. M. Ashton. 1962. The effect of 2-chloro-4-ethy lamino-6-isopropylamino-s-triazine (atrazine) on distribution of cl4-compounds following C1402 fixation in excised kidney bean leaves. J. Expt1. Bot. 13:5-11. 
131. Zubay, G. 1963. Molecular model for protein synthesis. Science 140:1092-1094. 


\section{BIOGRAPHICAL SKETCH}

The author, Raghvendra Pal Singh, was born on January 10, 1939, in the district of Basti, U.P., India. He passed his high school and intermediate examinations of Uttar Pradesh Board of High School in June 1953 and 1955, respectively. In 1955, he was transferred to Government Agriculture College, Kanpur (Agra University), from which he received the degrees of Bachelor of Science in Agriculture, in 1957, and Master of Science in Agriculture, with Agronomy as a major subject, in 1959.

He entered the University of Florida, Gainesville, in February 1962. He completed his work toward the degree of Doctor of Philosophy in the Department of Agronomy in December 1964. 
This dissertation was prepared under the direction of the chairman of the candidate's supervisory comittee and has been approved by all members of that committee. It was submitted to the Dean of the College of Agriculture and to the Graduate Council, and was approved as partial fulfillment of the requirements for the degree of Doctor of Philosophy.

December, 1964

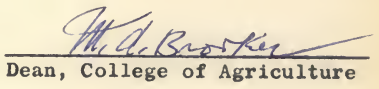

Supervisory Committee :

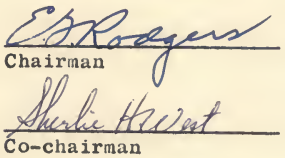

Dean, Graduate School
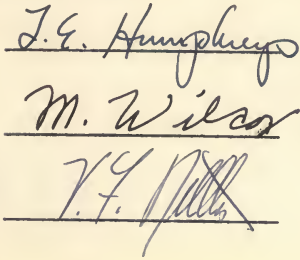